\title{
WISE MERCHANTS
}

On 20 November 1657, Pieter de la Court married Elisabeth Tollenaar, the daughter of a family of the ruling class of Leiden. Elisabeth's father and grandfather had been members of the veertigraad, the city council of forty local patricians of whom the four burgomasters of the town were elected annually through cooptation. Elisabeth's brother would join this municipal assembly a decade later, and the husband of her sister, Johannes Eleman, became a burgomaster of Leiden in 1659. ${ }^{1}$ To celebrate his entrance into this influential family, De la Court organized a lavish dinner for the guests at the wedding. A huge baked and gilded game pie stood at the centre of the table, surrounded by poultry and a pyramid of larks, hams, and a large sucking pig. This copious meal was accompanied by over sixty litres of hippocras, a typical wedding drink made of wine and spices. ${ }^{2}$ De la Court clearly took great pains to please his guests and behave as his new position required. Yet the marriage would not last long: before the year was out, Elisabeth had died in childbirth. De la Court remarried in 1661 with the daughter of a rich merchant family from Amsterdam. Meanwhile, he had become close friends with Eleman, whose connection to the governing establishment of the Dutch Republic eventually led to the publication of the bestselling Interest van Holland.

The marriage therefore proved to be of paramount importance for De la Court. It evidently improved the social status of his family, which continued to be conditioned by his father's foreign origins and nouveau riche characteristics - for many in Leiden a source of aversion. Here social tensions blended with xenophobia: the large group of Flemish immigrants who successfully made their way in the Leiden textile business often operated as independent entrepreneurs, bypassing the traditional

\footnotetext{
${ }^{1}$ For an analysis of the social, political, and cultural dimensions of the Leiden veertigraad in the seventeenth century, see Dirk Jaap Noordam, Geringde buffels en heren van stand. Het patriciaat van Leiden, 1574-170o (Hilversum: Verloren, 1996). For a general survey of early-modern Leiden politics, cf. S. Groenveld and Jan A.F. de Jongste, "Bestuur en beleid," in Simon Groenveld (ed.), Leiden. De Geschiedenis van een Hollandse stad, vol. 2: 1574-1795 (Leiden: Stichting Geschiedschrijving Leiden, 2003), 55-83.

${ }^{2}$ See the documents published in C. Willemijn Fock, "Het eerste huwelijk van Pieter de la Court in 1657," Leids Jaarboekje 74 (1982), 72-85.
} 
intermediaries and settled drapers. ${ }^{3}$ As a result, few of them were considered to be truly full members of society, even though they had, like De la Court sr., obtained the citizenship rights of the city. De la Court's marriage into the powerful Tollenaar family reveals that the second generation of wealthy immigrants could eventually enter the ranks of the civic establishment. Nonetheless, this gradual acceptance did not mean that burghers of alien descent were granted any significant political role in the Leiden council, which was ever more reserved to the closed regent oligarchy of a few well-established families. ${ }^{4}$

These issues of immigration, social acceptance, and civic participation in politics, of marriage and household, as well as the indulgence of lavish dinners, pivot on the key political concept of citizenship. This third chapter focuses on the social, political, and ethical aspects of this concept in the thought of the brothers De la Court. It shows that De la Courts constructed an account of commercial citizenship, whereby the merchant who honourably pursues his self-interest within the borders of civil discipline personifies the true republican citizen. I will analyze how this account of commercial citizenship develops from, first, the De la Courts' quasi-Hobbesian theory of the contractual foundation of civil society; second, from their criticism of the exclusivist corporate politics in Leiden; and third, from their mercantile interpretation of the Ciceronian ethics of honour and ambition. The resulting image of the wise merchant, revealed in the brothers' pictorial self-representation, is specifically significant for our understanding of seventeenth-century Dutch civic culture and the relation between commerce and citizenship in early-modern republicanism at large.

\section{Hobbes \& The Foundation OF THE COMMONWEALTH}

\section{From the State of Nature to a Democratic Polity}

The De la Courts' account of the origins and structure of civil society starts and ends with their assessment of the passionate condition of human

\footnotetext{
3 Van Tijn, "Pieter de la Court," 306-309. See also Dirk Jaap Noordam, "Textielondernemers en het Leidse patriciaat, 1574-1795," Textielhistorische bijdragen 36 (1996): 20-36, esp. 21-23.

${ }^{4}$ Noordam, Geringde Buffels, 36-41; and Idem, "De Leidse veertigraden in de lange zeventiende eeuw, 1574-1700," in Jaap Moes and Dirk Jaap Noordam (eds.), Macht, aanzien en welzijn. Nieuwelingen in het Leids stadsbestuur, 1200-1795 (Leiden: Primavera, 2003), 48-59.
} 
nature. As argued above, human nature is for the brothers De la Court shaped by the unsettling but also functional power of the passions. From the very first edition of the Politike Weeg-schaal, which starts with a discussion of the state of nature to explain the contractual foundation of the commonwealth, this characterization of human nature forms the basis of the analysis.

The initial version of the argument runs as follows. In a hypothetical state of nature, when political organization is still absent, life is totally dominated by the most elementary of all passions: self-love, the furthering of one's own "body, life, and honour". ${ }^{5}$ Such self-love has, on the one hand, positive consequences, since it drives all human beings to the fulfilment of their most basic instinct, their self-preservation. But on the other hand, it causes such competition, mistrust and hate that ultimately the preservation of every individual is jeopardized. This view echoes the French Augustinian emphasis on self-love as the essence, but therefore also the possible corruption, of humanity. ${ }^{6}$ Yet the De la Courts do not share the Augustinian answer to the disruptive consequences of self-love in terms of divine grace. Instead, their solution to overcome the detriments of natural self-love is entirely secular: the solution lies in politics as such. The relentless pursuit of self-love can only be restrained by fear, yet in the absence of any hierarchical power to inflict punishment, such fear for the other necessarily leads to mutual destruction. The result is endless warfare, and

(Homo homini Lupus in statu naturali) such a war of all men against all men is the most disastrous state of men which one could think of here on earth. And therefore it is in all ways necessary that some means are searched to get out of this dreadful natural state. For, although the ignorance and evil of men are so great that in this life no perfect human state or society will or can be found, it is nonetheless true that the most imperfect Government of the World, compared to this disastrous state of war of all men against all, could be called (Homo homini Deus in statu politico) a Paradise. ${ }^{7}$

5 Politike Weeg-schaal, "Inleyding," p. 13: "Vermits de naturelike Menschen boven alles haar eige lighaam, leeven en eere beminnen."

${ }^{6}$ Cf. Senault, De l'usage des passions, I.I.4, p. 41: “... nous ne reconnoissons qu'une passion qui est l'amour, \& que toutes les autres ne sont que des effects qu'il produit ... C'est un premier Mobile qui emporte tous les autres Cieux par son impétuosité."

7 Politike Weeg-schaal I.I.3, p. 22-23: “... (Homo homini Lupus in statu naturali) welke oorlog van alle menschen teegen alle menschen, de rampsaligste staat der menschen is die men hier op aarde zoude konnen bedenken. En dienvolgende zoo is in allen maniere noodzakelik, dat eenige middelen werden gezogt om uit deese ellendige naturelike staat te geraken: want howel de onweetendheid en boosheit der menschen, zoo groot is, dat in dit 
With these common lines about wolf-like versus god-like man, popularized in particular by Thomas Hobbes, ${ }^{8}$ the De la Courts confront the unruly state of nature with civil society, which channels human behaviour and enables people to preserve themselves without harming others. ${ }^{9}$ This concept of a state of nature clearly serves as a hypothetical construct to explain the inevitability of society, for "experience teaches that the natural state of men would necessarily breed Government and politics". ${ }^{10}$ The instinctive desire for self-preservation makes human beings realize that they should commit themselves to a political organization in which their self-love can be directed. Moreover, since all people in the state of nature are equally weak and needy, the use of force cannot lie at the basis of such a political society. The only option is to search for a peaceful pact with other individuals, a pact that ultimately establishes a government based on the consent of the majority of all contractors:

There is nothing more dreadful than the natural state (status naturalis) of men, because then they are all mutual enemies and in continuous anxiety. As a result, man should try to get out of this state of war against all men and obtain some help on this occasion. And because no men are by nature so mighty that they could compel others to help them, therefore they should necessarily try to obtain the same of others through pact. And since no-one would pact with them but on fair and equal conditions, so it follows that according to this fairness, they must necessarily devolve the right and power to rule to the majority."

leeven geen volmaakte menschelike staat, ofte societeit, sal, nog kan werden gevonden: zoo is nogtans waaragtig, dat de onvolmaakste Regeering des Weerelds, vergeleeken zijnde, by deezen rampsaligen oorlogs-stand, aller menschen onder malkanderen, (Homo homini Deus in statu politico) een Heemel zoude konnen werden genaamt." The first Latin phrase is also used in Welvaren 6, p. 14, the second in Aanwysing I.9, p. 44.

8 Thomas Hobbes, On the Citizen, ed. and trans. Richard Tuck and Michael Silverthorne (Cambridge: Cambridge Univerity Press, 1998), 3. Cf. Erasmus, Adages I.I.69-70, and John Owen, Epigrammata (London, 16o6), III.23: 'Homo homini lupus, Homo homini Deus'. See also François Tricaud, “'Homo homini Deus', 'Homo homini Lupus': Recherche des Sources des deux Formules de Hobbes", in Reinhart Koselleck and Roman Schnur (eds.), Hobbes-Forschungen (Berlin: Duncker \& Humblot, 1969), 63-71.

${ }^{9}$ Cf. the classical depictions of the state of nature and the origin of society in Cicero, De inventione I.2, and Niccolò Machiavelli, Discorsi sopra la prima deca di Tito Livio, ed. Corrado Vivanti (Turin: Einaudi, 2000) I.1-2.

${ }^{10}$ Politike Discoursen II.IV.2, p. 11-12: "De ervarendheid leerd dat de natuurlike stand der menschen, noodsaakelik de Regering, en politie soude uitbroejen." Cf. on the hypothetical state of nature in Hobbes, François Tricaud, "Hobbes's Conception of the State of Nature", in G.A.J. Rogers and Alan Ryan, Perspectives on Thomas Hobbes (Oxford: Clarendon Press, 1988), 107-123.

"Politike Discoursen II.V.7, p. 123-124: "Daar is niets ellendiger als de natuurrelikke stand (status naturalis) der menschen, dewyl zy als dan alle onderling vyanden, en in 
In short, the state of nature necessarily leads to the establishment of a civil society through contract, and the human condition implies that the terms of this contract necessarily involve a democratic sovereign power.

This fundamental argument that democracy is the elemental form of all political association forms the straightforward argumentation in the first edition of the Politike Weeg-schaal and in the Politike Discoursen - as explained above, probably largely written by Johan de la Court. While rewriting the Politike Weeg-schaal, his brother Pieter added two passages that broaden the line of reasoning. A first addition, clearly meant to ground the argument in the authority of natural law theory, states that self-preservation is not only a passion, but also a right, a right that "surpasses all other natural Laws; and all following civil Laws are founded on the same, or at least presuppose it". One of these natural laws, only to be broken when it conflicts with this primary natural right, is the golden rule "do as you would be done by". This passage ends with a brief yet telling remark: "See all this more broadly and clearly proven by Th. Hobb. Elem. Phil. De Civ." ${ }^{\text {"2 }}$ De la Court's second addition clarifies the conditions under which a civil society is formed, and then continues to claim the necessary indivisibility of the thus established sovereignty. A separation of powers would mean a contradictio in adjecto, De la Court asserts, and in obvious reference to the debate on provincial sovereignty in the Dutch Republic, he insists that "the sovereign right to command and to make laws cannot be separated from the sovereign right to execute everything and to be obeyed." ${ }^{13}$ Again, this passage ends with a significant remark: "He who desires to see all this more broadly should read Thom. Hobbes Elem. Phil. de Cive, Power of a Commonwealth and le Corps politique." ${ }^{14}$

gedurige ongerustheid zijn: en dienvolgende soo moet de mensch tragten uit deesen oorlogsstand teegen alle menschen te geraaken, ende eenige hulp in deese geleegentheid te bekomen. En dewijl geen menschen van nature soo magtig zijn, dat zy andere souden konnen dwingen om haar te helpen; soo moeten zy noodsaakelik van anderen, door verdrag 't selven tragten te bekomen. En vermits niemand met haar, als op billike en gelijke conditien soude willen verdragen, soo volgd hier uit, dat zy volgens deese billikheid, noodsakelik het regt, ende magt van gebieden, aan de meeste stemmen moeten ooverdragen."

${ }_{12}$ Politike Weeg-schaal I.I.1, p. 16: “... het naturelik regt tot onze eige conservatie, alle andere naturelike Wetten te boven gaat: en alle volgende civile Wetten op het selven regt zijn geboud, ofte ten minsten het zelven presupponeren ... Sie dit alles breeder en klaarder beweezen by Th. Hobb. Elem. Phil. de Civ." Cf. Hobbes, On the Citizen I.8-9, III.26.

${ }^{13}$ Politike Weeg-schaal I.I.4, p. 28: "... dat het souverain recht, om te gebieden, en wetten te maken, niet kan werden gescheiden van het souverain recht, om alles te executeeren, en zig te doen gehoorzamen." This statement is explicitly connected to the situation in the Dutch Republic on p. 31-32.

${ }_{14}^{14}$ Ibidem, 31: "Die dit alles breeder begeert te sien, leeze Thom: Hobbes Elem: Phil: de Cive. Power of a Commonwealth. en le Corps politique." 
De la Court thus revealed the obvious source of his statements, the recent works of Thomas Hobbes - respectively, De Cive, first published by Elzevier in 1647 , the Leviathan (1651, with as subtitle The Matter, Forme \& Power of a Commonwealth), and the French translation of De corpore politico, published in 1652. ${ }^{15}$ These short references have been the subject of substantial attention in the historiography to date, which has resultes in a widespread interpretation of the De la Courts' account of the state of nature and the contractual foundation of the commonwealth as the essential link between the political thought of Hobbes and Spinoza. As Kossmann put it bluntly in 1960, De la Court "was a pupil and disciple of Hobbes", and "it was of course Hobbes who persuaded De la Court to reject the traditional idea that men first entered the state fully equipped with morality and religion". ${ }^{16}$ This supposedly essential Hobbesian influence on the thought of the brothers De la Court has since been restated by other historians without question - with the sole exception of Hans Blom in his later work. ${ }^{17}$ Moreover, it has been argued repeatedly that this Hobbesian influence turned the De la Courts into the "mediators between Hobbes and Spinoza", ${ }^{18}$ or indeed the "medium" between the two. ${ }^{19}$ As Noel Malcolm maintains, the brothers De la Court constructed a theory in which "the Hobbesian overtones are obvious", a "theory built on thoroughly Hobbesian foundations". Thus, Malcolm argues, they contributed to a "Dutch Hobbesian-republican tradition" which formed the background to Spinoza's political philosophy. ${ }^{20}$

The question arises as to whether these statements offer a fruitful interpretation of De la Court's short references to Hobbes. First of all, the brothers De la Court obviously did not intend to form a 'medium' between Hobbes and Spinoza - a characterization that involves a teleological approach in which historical actors are primarily interpreted ex post facto,

${ }_{15}$ Hobbes, Le corps politique ou les elements de la loy morale et civile ([Rouen], 1652).

${ }^{16}$ Kossmann, Political Thought in the Dutch Republic, 61, 63, 78.

${ }^{17}$ See e.g. Van Tijn, "Pieter de la Court," 331-333; Haitsma Mulier, "Pocock and Seventeenth-Century Dutch Republicanism," 26-27; Visentin, "Assolutismo e libertà," 78; Van Bunge, From Stevin to Spinoza, 86-87. Cf. Blom, Morality and Causality, 159-160, and Israel, Enlightenment Contested, 231-236.

${ }_{18}$ Wolfgang Röd, "Van den Hoves 'Politische Waage' und die Modifikation der Hobbesschen Staatsphilosophie bei Spinoza," Journal of the History of Philosophy 8 (1970), 29-48: 29 .

${ }_{19}$ M.J. Petry, "Hobbes and the Early Dutch Spinozists," in C. de Deugd (ed.), Spinoza's Political and Theological Thought (Amsterdam, 1984), 150-170: 154.

${ }^{20}$ Malcolm, Aspects of Hobbes, 44-47,515. Cf. also Alexandre Matheron, "The Theoretical Function of Democracy in Spinoza and Hobbes," in Genevieve Lloyd (ed.), Spinoza. Critical Assessments, 3 vols. (London and New York: Routledge, 2001), vol. III: 112-121. 
with hindsight of later developments. Secondly, the inclination to position these historical actors between the canonized grand old men of the history of political thought reveals a clear preference for those authors and texts which have passed the tests of time and can therefore be seen as constitutive of modernity. Again, such an inclination likely does not do justice to the past relevance and meaning of texts and statements. The interesting question to ask is not how the De la Courts connected Hobbes and Spinoza, but why and how exactly they appropriated Hobbes in their theory. What do the references to Hobbes's works actually reveal about the brothers' intentions in reading Hobbes?

\section{Reading Hobbes as a Republican}

Hobbes's political philosophy enjoyed a broad and early reception in the Dutch Republic after the first publication of De Cive. ${ }^{21}$ Samuel Sorbière, a French contact of Hobbes who enrolled as a student in 1646 at Leiden University where he attended Heereboord's classes, had brought a copy of De Cive to the Netherlands which was published in 1647 by Elzevier. The work, which was sold out and reprinted within a year, had a large impact, and the discussions about the work reflected clear political positions in the Dutch debate. On the one hand, the Calvinist clergy reproached Hobbes for his moral relativism and allegedly 'Machiavellian' concept of absolute sovereignty, as well as for his subjection of ecclesiastical affairs to the civil magistrate, one of the main controversies in seventeenth-century Dutch politics. ${ }^{22}$ On the other hand, an important critic of Calvinist orthodoxy, the Utrecht regent Lambert van Velthuysen, openly declared himself a disciple of $D e$ Cive, although he did so by fundamentally altering Hobbes's subjectivism into a Grotian theory of natural human sociability. ${ }^{23}$ Thus Hobbes was soon mobilized by different sides in the Dutch debate as either immoral scapegoat or anti-clerical inspiration.

${ }^{21}$ See Cornelis W. Schoneveld, Intertraffic of the Mind. Studies in Seventeenth-Century Anglo-Dutch Translation (Leiden: Brill, 1983), 29-46; Catherine Secretan, "La reception de Hobbes aux Pays-Bas au XVIIe siècle," Studia Spinozana 3 (1987), 27-45; and the large overview by Noel Malcolm, "Hobbes and the European Republic of Letters," in Idem, Aspects of Hobbes, 457-545.

${ }^{22}$ See Gisbert Cock, Exercitationis philosophica-theologicae, de lege in communi (Utrecht, 1653), and Idem, Vindiciae pro lege \& imperio: sive dissertationes duae ... contra tractatum Hobbii De Cive (Utrecht, 1661), esp. 82-88. Cf. Secretan, "La reception de Hobbes," 28-31; and Malcolm, "Hobbes and the European Republic of Letters," 475-477.

${ }_{23}$ [Lambert van Velthuysen], Epistolica dissertatio de principiis iusti, et decori, continens apologiam pro tractatu clarissimi Hobbaei, De Cive (Amsterdam, 1651). See on Van Velthuysen's reading of Hobbes in particular Blom, Morality and Causality, 101-128; 
Given this initial politicized reception of Hobbes in the Dutch Republic, it is likely that the brothers De la Court were introduced to Hobbes's writings in the course of the 165 os. Nonetheless, there is an important caveat here, for textual evidence suggests that this introduction to Hobbes might have arrived fairly late in the development of their thought, perhaps only after Johan's death in 166o. First of all, the references to Hobbes in the Politike Weeg-schaal were, as noted above, only included by Pieter in the later re-editions to clarify passages that had not been present in the first edition. Secondly, the earliest manuscript of Het welvaren van Leiden, which probably dates from the autumn of 1659 , does not mention Hobbes at all, while the later versions of the text, from after 1660 , contain a passage on absolute sovereignty that approvingly refers to Hobbes. ${ }^{24}$ In sum, the few parts of the brothers' works that directly rest on Hobbes were most probably written by De la Court after his brother's death. There are some phrases in the first edition of the Politike Weeg-schaal that hint at least to a superficial reading of De Cive, such as the characterization of the state of nature as a war of all against all, or the predominance of fear and distrust among humans. ${ }^{25}$ Yet overall, the confrontation with Hobbes, pace Kossmann and others, does not seem to have been a fundamental theoretical starting-point for the development of the thought of the De la Courts.

Instead, their reading of Hobbes implies primarily a partisan (and highly partial) appropriation of his political philosophy in the context of Dutch republican politics. This appropriation is exemplified by the 1667 Dutch translation of the Leviathan by Abraham van Berkel, a former student at Leiden in theology and medicine. ${ }^{26}$ In his introduction to the work, Van Berkel compared the execution of Charles I in 1649 with the attempted coup d'état by the Dutch Stadholder a year later: both were

Malcolm, "Hobbes and the European Republic of Letters," 517-518; and Jon Parkin, "Taming the Leviathan: Reading Hobbes in Seventeenth-Century Europe," in T.J. Hochstrasser and P. Schröder (eds.), Early Modern Natural Law Theories. Contexts and Strategies in the Early Enlightenment (Dordrecht etc.: Kluwer, 2003), 31-52: 36.

${ }^{24}$ Cf. Groningen University Library, Ms 233: "t Welvaren der Stad Leyden," fol. 127, with Welvaren 71, p. 154-155. On the dating of this manuscript, see Lucassen, "Het Welvaren van Leiden."

${ }^{25}$ Cf. Politike Weeg-schaal I.I.1, p. 17-18, with Hobbes, On the Citizen, 10, 25.

${ }^{26}$ See Schoneveld, Intertraffic of the Mind, 46-63, and Arie-Jan Gelderblom, "The Publisher of Hobbes's Dutch Leviathan," in Susan Roach (ed.), Across the Narrow Seas. Studies in the History and Bibliography of Britain and the Low Countries (London: The British Library, 1991), 162-166. The library of Pieter de la Court van der Voort contained a copy of Van Berkel's translation and the 1668 edition of Hobbes's Opera Philosophica Omnia, published by Blaeu, but no earlier copies of Hobbes's works: Library, fols. 20, 24. 
illegitimate deeds, he argued, which resulted from a fundamental misunderstanding of the absolute nature of sovereignty in England and the United Provinces. For Van Berkel, Hobbes's argument against the English tyrannicides was therefore also an argument against the Dutch Orangists a highly telling volte-face that mobilized Hobbes for the cause of the provincial sovereignty of the States of Holland. Moreover, Van Berkel insisted that the Leviathan exemplarily revealed the extent of civil liberty and the subordination of ecclesiastical power to the civic magistrate. ${ }^{27}$ In short, he turned Hobbes into a Dutch anti-Orangist republican.

Van Berkel was the central figure of a small circle of Leiden intellectuals which included Pieter de la Court, to whom Van Berkel referred in his 1665 translation of Thomas Browne's Religio Medici as a "trustworthy Friend, that well-trained Mind, the Author of Holland's Interest" ${ }^{28}$ Among the other friends of Van Berkel were Janus Rampius, a teacher related to the governing circles of Leiden by marriage, the Englishman Joseph Hill, who a decade later published a political pamphlet on the relations between England and the United Provinces which directly echoed the De la Courts, ${ }^{29}$ and Adriaen Koerbagh, a radical freethinker whose first publication involved a strong defence of the provincial sovereignty of the States of Holland. In the wake of the political crisis of 1650 , Hobbes's political philosophy offered these critical intellectuals an innovative theoretical framework to cope with the fundamental yet undecided question of political obligation. As Jon Parkin has argued convincingly regarding the reception of Hobbes in England, "Hobbes's works made sense of a world of political and religious conflict in a way that more traditional political theory did not"..$^{\circ}$ The same can be said of his reception in the Dutch Republic: for many of his readers in an age defined by political contingency, Hobbes's compelling characterization of civil disorder and the foundation of absolute sovereignty implied a new, potent means to come to terms with de facto politics.

${ }^{27}$ Hobbes, Leviathan: of van de stoffe, gedaente, ende magt van de kerckelycke ende wereltlycke regeeringe, trans. Abraham van Berkel (Amsterdam, 1667), "Voor-reeden," sigs. ${ }^{*} 4{ }^{-*} 5$.

${ }_{28}^{28}$ Religio Medici. Dat is: Noodwendige beschryvinge van Mr Thomas Browne, trans. Abraham van Berkel ('Laege-duynen' [=Leiden], 1665), 238, note 2: "Mijn vertrouden Vrient, dat wel-geoeffende Verstant, den genoemden Autheur van 't Hollands-Interest."

${ }^{29}$ [Joseph Hill], The Interest of These United Provinces, Being a Defence of the Zealander's Choice (Middelburg, 1673), which refers to the Politike Weeg-schaal. See Schoneveld, Intertraffic, 4-6, 38-39, 142, note 21.

${ }^{30}$ Jon Parkin, Taming the Leviathan. The Reception of the Political and Religious Ideas of Thomas Hobbes in England, 1640-1700 (Cambridge: Cambridge University Press, 2007), 205. 
The way in which Hobbes was appropriated by the brothers De la Court equally stems from this novel potential of his ideas. The De la Courts found in Hobbes an authoritative source for three important elements of their theory: the depiction of natural equality and mutual fear as the foundations of political organization, the ensuing argument that all government originates as democracy, and the eventual classification of sovereignty as necessarily absolute and undivided. None of these three issues are exclusively Hobbesian, and therefore it does not make much sense to speak of the De la Courts as Dutch disciples of Hobbes. Instead, the brothers turned to Hobbes to further substantiate their views on the basis of his evocative, though ambiguous, language. Hobbes's rhetorical strategies defied a straightforward reading, as Jon Parkin has shown, and one of the main reasons for his influence in the seventeenth century was his ability to entrap the reader and thus address different political agendas - even the radical republican agenda of the brothers De la Court..$^{31}$

The writings of Hobbes offered the De la Courts compelling new evidence of what they had been taught when studying at Leiden. The politica of their professor Boxhorn gradually moved away from the Aristotelian notion of man as a political animal to a depiction of human nature as essentially self-interested. For Boxhorn civil society originated in necessity and fear, a view shared by other important seventeenth-century scholars on politica such as Henning Arnisaeus, who equally acknowledged fear as an important factor in the establishment of politics,,$^{32}$ or the Helmstedt professor Johann Werdenhagen, for whom "fear and indigence" lay at the basis of every commonwealth. ${ }^{33}$ Hobbes, in particular in De Cive, developed this view into a suggestive image of the state of nature that amounted to a full-blown repudiation of Aristotle. In far more compelling detail and expressive language than his academic predecessors, Hobbes emphasized the fundamental equality of power among all natural human beings. It is this equal "power to kill" that makes mutual fear, and

${ }^{31}$ Ibidem, 86, and Parkin, "Taming the Leviathan," esp. 37.

${ }^{32}$ Henning Arnisaeus, De republica, seu reflectionis politicae libri II (Strasbourg, 1636) I.I.2.8, p. 9. On Arnisaeus, see Horst Dreitzel, Protestantischer Aristotelismus und absoluter Staat. Die "Politica" des Henning Arnisaeus (ca. 1575-1636) (Wiesbaden: Franz Steiner Verlag, 1970).

${ }^{33}$ Johannes Angelius Werdenhagen, Universalis introductio in omnes respublicas sive politica generalis (Amsterdam, 1632) II.II.9-13, p. 219-221. Cf. Alfred Voigt, Über die Politica generalis des Johann Angelius v. Werdenhagen (Amsterdam 1632) (Erlangen, 1965), and Rolando Crahay, "Dalla République di Jean Bodin alla Synopsis di Johann Angelius Werdenhagen (1635). Un rinnovamento dei concetti religiosi e politici," Rivista Storica Italiana 104 (1992), 629-677. 
not benevolence, the origin of society. ${ }^{34}$ This emphasis on natural equality was readily adopted by the brothers De la Court. All men are by nature equal in their strengths and passions, and

out of this natural equality arise commonly mutual fear, modesty, and morality, for one feels ashamed and does not dare to desire that others endure from us what we would not want to suffer from others. And since human privation is meanwhile large, and the order to get out from that misery and privation necessary, therefore one very easily, in all diversity of judgment, concedes this fairness: that reasonably, few should comply with the judgment of many. And this natural fairness and rationality is the foundation of all Democratic, or Popular, Governments. ${ }^{35}$

This revealing passage makes clear that the De la Courts eagerly connected Hobbes's evocative depiction of the state of nature with his secondary argument that democracy is the original form of all government. In De corpore politico, the second part of the treatise titled The Elements of Law in the English version, Hobbes argued that democracy must be necessarily "first in order of time", because both aristocracy and monarchy can only be instituted by the consent of the majority. ${ }^{36}$ This idea that democratic consensus must lie at the basis of every commonwealth was, again, not particularly original. Although, for example, Boxhorn maintained that monarchy and aristocracy precede democracy, Johannes Althusius had insisted at the start of the seventeenth century that all commonwealths originate in consent, never in coercion. ${ }^{37}$ Hobbes merely restated this conventional view, but he did so rather ambiguously (and perhaps hastily). ${ }^{38}$ The argument that democracy is the original form of government plays a minor, even anomalous role in his political philosophy, and it gradually

34 Hobbes, On the Citizen I.2-3, p. 21-26.

35 Politike Weeg-schaal III.I.2-3, p. 521, 524-525: "Naademaal volwasse Mannen moeten werden geconsidereert gelijk te zijn in naturelike kragten ... zoo ontstaat gemeenelik uit die naturelike gelijkheid en onderlinge vreese, modestie, en zeedigheyd; zulks men zich schaamt, en niet derfd begeeren dat anderen van ons verdragen, 't gunt wy van anderen niet zouden willen lijden. En vermits onderwijlen de menschelike behoeftigheid groot, en de ordre om uit die ellende en behoeftigheid te geraken noodsaakelik is, zoo staat men zeer ligtelik, in alle verscheidentheit van oordeel, dese billikheit toe, dat reedeliker-wijse, weinigen zig behooren te voegen naa het oordeel van veelen. Welke naturelike billik- en reedelikheit de gront-slag is van alle Demokratike, ofte Populare Regeeringe."

${ }^{6}$ Hobbes, The Elements of Law Natural and Politic, ed. Ferdinand Tönnies, 2d. ed. (London: Frank Cass, 1969) II.II.1, p. 118; Idem, Les corps politiques, 73.

37 Cf. Boxhorn, Institutiones politicae II.I Exp., p. 26o, with Johannes Althusius, Politica methodice digesta, 3d. ed. (Herborn, 1614) IV.1.

$3^{8}$ See Deborah Baumgold, "The Composition of the Hobbes's Elements of Law," History of Political Thought 25 (2004), 16-43. 
disappears almost entirely in the development from The Elements of Law to De Cive and eventually to Leviathan. ${ }^{39}$ Yet the De la Courts appropriated this ambiguous argument from Hobbes for their own ensuing claim that all sovereignty is by necessity popular. As the Politike Weeg-schaal insists (in a passage added to the first edition, so perhaps written by De la Court after having read Hobbes): "Democracy or Popular Government is the oldest and most legitimate one. For no Assembly can charge a sovereign power to someone else, when it does not possess this itself." ${ }^{\circ 0}$ Thus, what was for Hobbes a secondary claim became in the work of the De la Courts a central element of their republican theory.

The brothers De la Court could adapt Hobbes in this way because they looked at his work through Grotian lenses with a fairly radical focus. ${ }^{41}$ Hobbes's subjectivism, coined in a language of rights, is turned by the De la Courts into a language of 'fairness', in which rights do not play any significant role. For the De la Courts, the natural equality among human beings leads not only to mutual fear but also involves natural justice and morality. It is such morality which enables the contractual foundation of the commonwealth along rational and democratic lines. This argument merges the Hobbesian prominence of fear with a Grotian emphasis on mutual human recognition, primarily based on the Stoic notion of oikeiosis, the natural inclination to self-protection and common support. ${ }^{42}$

39 Cf. Hobbes, On the Citizen VII.5, with Leviathan XVIII.1. On democracy in Hobbes, see the debate between Richard Tuck, "Hobbes and Democracy," and Kinch Hoekstra, "A Lion in the House: Hobbes and Democracy," in Annabel Brett et al. (eds.), Rethinking the Foundations of Modern Political Thought (Cambridge: Cambridge University Press, 2006), 171-218.

$4^{40}$ Politike Weeg-schaal I.I.7, p. 36: “... dat de Democratie ofte Populare regeering de oudste en wettelikste is. Want geen Vergaadering, aan een ander een souveraine magt kan opdraagen, indien zy die zelfs niet heeft."

${ }^{41}$ The library of Pieter de la Court van der Voort contained the four volumes of Grotius's Opera omnia (1679), and also editions of Van de oudheijd van de Batavische republyk (The Hague, 1610), Van de wettige regeering van Holland (Paris, s.d.), De jure belli ac pacis (Amsterdam, 1631), De mare libero (Leiden, 1633), and Annales et historiae Belgicae (Amsterdam, 1647): Library, fols. 10, 15, 19, 22, 31.

${ }^{42}$ Cf. Grotius, Commentary on the Law of Prize and Booty, ed. Martine Julia van Ittersum (Indianapolis: Liberty Fund, 2006), esp. 26-28, and The Rights of War and Peace, trans. William Evats (London, 1682), iii-v. For the notion of oikeiosis, see Reinhard Brandt, "SelfConsciousness and Self-Care. On the Tradition of Oikeiosis in the Modern Age," Grotiana (New Series) 22/23 (2001-2002), 73-92; and Benjamin Straumann, "Oikeiosis and appetitus societatis. Hugo Grotius's Ciceronian Argument for Natural Law and Just War," Grotiana (New Series) 24/25 (2003-2004), 41-66. For a more general comparison between Grotius and Hobbes, see Tuck, Philosophy and Government, 303-306, 347-348; and Knud Haakonssen, Natural Law and Moral Philosophy from Grotius to the Scottish Enlightenment (Cambridge: Cambridge University Press, 1996), 26-35. Cf. as well the criticism by Johann 
The De la Courts also adapt Hobbes in a Grotian manner by insisting on the fundamental preservation of sovereignty among the democratic assembly that forms the basis of all government. For Hobbes, the contractual institution of sovereignty turns a multitude of individuals into a unified body of people, and therefore the people cannot set limits to the exercise of that sovereignty. ${ }^{43}$ Yet for the De la Courts, the initial consent that lies at the basis of government implies that all legitimate sovereign power remains in principle with the people - a claim evocatively epitomized in a number of fables that recount how sheep and foxes meet in their animal assembly to discuss the affairs of their community. ${ }^{44}$

This view, rooted in Monarchomach thought and the traditional justification of the Dutch Revolt, clearly involves a crucial departure from Hobbes. Yet more importantly, it also entails a significant reinterpretation of conventional contract theory, including that of Grotius. The work of the De la Courts argues that the hypothetical passage from the state of nature to a political society can proceed along two diametrically opposed lines: either all "would make a mutual civil society, or pacts and laws, and choose Magistrates to let them provide for the benefit of the community, and so create a free Republic"; or the strongest man would prevail by force or deceit and "would thus establish a Monarchy". ${ }^{45}$ In other words, all government by consent is necessarily republican, while monarchy necessarily originates from forceful coercion and is hence no true civil society. This differentiation between democratic government by institution and monarchical government by acquisition is also central to Hobbes, but the essential difference from Hobbes (and most other contract theorists) here is the consequent claim that monarchy can never derive from consent and is therefore essentially illegitimate. ${ }^{46}$ The central passion of self-love, so the argument of the brothers De la Court goes, makes it impossible that any human being would think that another is more competent to rule,

P. Sommerville, "Selden, Grotius, and the Seventeenth-Century Intellectual Revolution in Moral and Political Theory," in Victoria Kahn and Lorna Hutson (eds.), Rhetoric and Law in Early Modern Europe (New Haven: Yale University Press, 2001), 318-344.

43 See Quentin Skinner, "Hobbes and the Purely Artificial Person of the State," in Idem, Visions of Politics, 3 vols. (Cambridge: Cambridge University Press, 2002), vol. III: 177-208.

44 E.g. Sinryke Fabulen, 301-308, 355-362.

45 Politike Discoursen I.I.1, p. 1-2: “... een onderlinge civile societeit, ofte verbonden en wetten maken, ende Magistraten kiesen, om die tot nut van 't gemeen te doen onderhouden, ende alzoo een vrye Republijck te formeeren. Of de sterkste en looste sig van veelen, d'een voor d'ander naa, 't zy door kragt, 't zy door bedrog, meester gemaakt hebbende, soude een Monarchie opregten." Cf. also Ibidem II.V.9.

${ }^{46}$ Cf. esp. Hobbes, Elements of Law II.II.9; On the Citizen VII.11-17. 
since "men have naturally such a large presumption of their own capability that they will never have willingly and knowingly charged the power to promote their own advantage to some others, however those may be". ${ }^{47}$ Therefore, it is "unthinkable ... that a popular Government has ever authorised one man and his descendants for all eternity" to be sovereign, since "it cannot be presumed at all that there has ever been the least intention from any popular Assembly to take away the own power of choosing, in case of incapability or malevolence of a Ruler and his Successors, a much more capable or better one".$^{8}$ In short, because of human nature, the democratic assembly that forms the basis of all government always retains sovereignty. A hereditary monarchy can only originate in the illegitimate usurping of this original popular government by force or deceit.

For Samuel Pufendorf, who read the Politike Weeg-schaal in the years he spent in the Dutch Republic during the early 166os, this view of the inconceivability of a chosen hereditary monarchy was merely a "pestilens dogma", clearly refuted by the philosophy of Hobbes. ${ }^{49}$ Yet it is more significant that the brothers De la Court not only departed from Hobbes, but essentially employed the Hobbesian characterization of the human condition to reinterpret the contract theory that Hobbes himself argued against. This contract theory is exemplified by the English supporters of Parliament in the 1640s, particularly by Henry Parker's Observations of 1642 - published a few months before Pieter de la Court was in London for his Grand Tour. Parker's main argument in favour of parliamentary sovereignty was "that power is but secondary and derivative in Princes, the fountaine and efficient cause is the people". ${ }^{50}$ Hobbes's reply was intended

${ }^{47}$ Politike Weeg-schaal III.I.2, p. 523: “... waaragtig, de menschen naturelik soo groote presumptie van hare eige bequaamheit te hebben, dat sy nooit willens en wetents, de magt van haar eigen voordeel te betragten, aan eenige anderen, hoedanig die zijn, sullen hebben opgedragen."

${ }^{48}$ Ibidem I.I.7, p. 37: “... onbedenkelik te zijn, dat ooit een populare Vergaadering daar toe hebbe geauthoriseerd een mensch, en zijn afkomelingen inder eeuwigheid ... zoo kan gantsch niet werden gepresumeerd ooit de minste intentie eeniger populare Vergaderinge te zijn geweest zig zelven te beneemen de magt van by onbequaam-of quaadwilligheid eens Regeerders en zijner Successeurs, te kiezen een veel bequamer of beeter." Cf. also Ibidem III.I.2-3, III.III.3.

49 Samuel Pufendorf, De jure naturae et gentium libri octo (1688, facs. ed. Oxford: Clarendon Press, 1934) VII.V.9, p. 706-707, quoting Politike Weeg-schaal I.I.7, p. 37-38. Cf. as well Ibidem VII.V.22, p. 721: "Ex adverso nihil, quod in monarchas maligne aut invidiose dici queat, videtur omisisse scriptor Belgicus Bilancis politicae. Quorum tamen non pauca retundi possunt per cap. X Hobbesii de Cive, \& Leviath.c.19."

$5^{\circ}$ [Henry Parker], Observations upon Some of His Majesties Late Answers and Expresses [London, 1642], 2. See Michael Mendle, Henry Parker and the English Civil War. The Political Thought of the Public's 'Privado' (Cambridge: Cambridge University Press, 1995), 85-88. 
to make clear that this view was both absurd and dangerous, since a division of sovereign power would necessarily entail the dissolution of the commonwealth, and thus a return to the state of nature where every single individual exercises the right of self-preservation..$^{51}$ The De la Courts adopt this argument, but they do so to argue that human selfishness in the state of nature makes it a priori absurd to conceive of a monarchy instituted by consent. They thus use Hobbes's own weapons against Hobbes, while their repudiation of the primacy of monarchy equally undermines the space allocated to kings in the work of Grotius and Parker..$^{52}$ In the political universe of the De la Courts, monarchies might be successful polities, but they cannot be true civil societies based on popular consent.

Finally, the brothers De la Court also appropriate the Hobbesian argument that "the Sovereign is always One, or indivisible" - yet they do so again in a quasi Grotian way. ${ }^{53}$ In reaction to Bodin, Grotius had argued that sovereignty in Holland originated from the people but was administered by the provincial States. In this way Grotius attempted to reconcile Bodin's absolutism with the time-honoured ideal of the mixed regime. This view went back to the period of the Dutch Revolt, when François Vranck, pensionary of the town of Gouda, had written a defence of the sovereignty of the States of Holland, the "Magna Carta of the Dutch Republic", in reply to claims for princely authority. ${ }^{54}$ Hobbes's notion of absolute sovereignty offered the De la Courts a new, powerful source to radicalize this established justification of provincial sovereignty. The result is a sort of republican absolutism, which emphasizes the indivisibility of sovereignty to counter any claims on behalf of a political or military role for the Stadholder, while ardently defending the supreme authority of the States of Holland in all religious and political matters. Thus, like

${ }^{51}$ See esp. Hobbes, Leviathan XVIII, p. 236-238.

$5^{2}$ Cf. Grotius, Rights of War and Peace I.III.9, p. 37-41. For the recent republican reinterpretation of Grotius, see esp. Tuck, Philosophy and Government, 154-201; Annabel Brett, "Natural Right and Civil Community: The Civil Philosophy of Hugo Grotius," The Historical Journal 45 (2002), 31-51; and Martin van Gelderen, "The State and its Rivals in EarlyModern Europe," in Quentin Skinner and Bo Stråth, eds., States and Citizens. History, Theory, Prospects (Cambridge: Cambridge University Press, 2003), 79-96.

53 Politike Weeg-schaal I.I.4, p. 23: "... dat de Souverain altijds Een, ofte onsplitsbaar is." Cf. Hobbes, On the Citizen VI.5-18, XII.5.

${ }_{54}$ François Vranck, Short Exposition (1587), in Martin van Gelderen (ed.), The Dutch Revolt (Cambridge: Cambridge University Press, 1993), 227-238. Vranck's text was republished several times throughout the seventeenth century as an appendix to the re-editions of Boxhorn's Commentariolus. See also the analysis in Van Gelderen, Political Thought, 204-205. 
Van Berkel, the brothers De la Court employ Hobbes's absolutism to reach a conclusion that would probably have horrified Hobbes himself. For the De la Courts, the popular origin and preservation of sovereignty means that a division in sovereignty would entail a violation of the contract that lies at the basis of political society. When the legislature is separated from the executive, individuals gain the opportunity to assume all military command, whereby the power of arms prevails over legitimate rule and all people are again entrenched in mutual warfare:

For it is clear that in all cases of a separation of the sovereign authority, these independent, divided people would have to guard against each other, and that the weakest would be devoured by the strongest, so that the natural state of war would in fact be introduced again..$^{55}$

Civil society, which originates from the human need to escape the war of all against all, would fail in its purpose when sovereignty is divided between different bodies. The eventual result can only be conflict and the abuse of powers, a gruesome fate exemplified by a fable that tells how a lion illegitimately gets hold of all authority in a badly ordered animal republic..$^{5}$ To overcome this monarchical state of affairs, sovereignty must remain absolute and located with its original possessors, the people. The brothers De la Court thus give a decisive republican twist to Hobbes's political philosophy.

This republican appropriation of Hobbes was not unique. Contemporary English republicans, notably Marchamont Nedham and James Harrington, equally adopted elements from Hobbes to sustain their defence of the English Commonwealth. Arguably, the lasting influence of Hobbes is due to precisely this capacity to speak to many different political agendas. ${ }^{57}$ Yet the rather arbitrary and highly partisan way in which the De la Courts adapted Hobbesian arguments means that their thought should not too hastily be labelled as belonging to a certain school of thought, be it 'Hobbesian', 'Grotian', or 'Cartesian'. Instead, like most early-modern political thinkers and pamphleteers, the brothers seem to have chosen whatever suited their argument eclectically from a range of sources, with

55 Politike Weeg-schaal I.I.4, p. 26: "Want het is klaar, dat in alle gevallen van verdeeldheid der souveraine magt, deeze independente verdeelde menschen, gedurig tegen malkanderen zouden moeten waaken; en dat de swakste door de sterkste zoude werden verslonden, zulks metter daad de naturelike oorlogs-stand weederom zoude weezen ingevoert."

${ }^{6}$ Ibidem, 29-30, more extensively in Sinryke Fabulen, 27-32.

57 See Parkin, Taming the Leviathan, 78-79, 178-185; Sullivan, Machiavelli, Hobbes, 165173; and Rahe, Against Throne and Altar, 321-346. 
more concern for rhetorical force than for scholastic consistency. Their diverse reading brought them in due course to the en vogue writings of Hobbes, which offered a temptingly novel outlook on de facto politics and the question of political obligation, the crucial issue in the 1650 os on either side of the North Sea. In constructing their account of the foundation of the commonwealth, they extracted a few of Hobbes's ambiguous views, discarded all the rest, and distilled the residue into an explosive brew that radicalized conventional contract theory with the claim that any legitimate form of political society must necessarily be non-monarchical.

\section{Citizenship in Theory ANd Practice}

\section{The Acquisition \& Limits of Urban Citizenship}

This account of the contractual origins of politics, based on the hypothetical passage from the state of nature to civil society, plays an important normative role in the political thought of the brothers De la Court. In contrast, their approach to the ensuing question of who actually counts as a citizen in this civil society is far less systematic and does not follow from any rigorous theoretical framework.$^{58}$ This section therefore turns primarily to the practice of citizenship in the seventeenth-century Dutch Republic and considers how the De la Courts conceived of the extent and limits of citizenship in relation to, and criticism of, the urban corporate politics of the Dutch Golden Age.

In the communal tradition of the early-modern Netherlands, as in Renaissance Italy, the embodiment of the commonwealth was the city. This centrality of the city implied that politics was by definition considered to be civic, i.e. taking place in an urban framework, as is reflected in the contemporary Dutch usage of the term politicus as 'burgherlick', for example in the influential late sixteenth-century treatise on citizenship by the Dutch engineer Simon Stevin. ${ }^{99}$ This urban emphasis equally dominates in the thought of the brothers De la Court. The starting-point of

\footnotetext{
${ }^{5}$ Hans W. Blom, "Burger en belang: Pieter de la Court over de politieke betekenis van burgers," in Kloek and Tilmans (eds.), Burger, 99-112.

59 Simon Stevin, Het burgherlick leven, ed. Pim den Boer (Utrecht: Bijleveld, 2001), esp. 34-37. See also Manfred Riedel, "Bürger, Staatsbürger, Bürgertum," in O. Brunner, W. Conze and R. Koselleck (eds.), Geschichtliche Grundbegriffe. Historisches Lexikon zur politischen-sozialen Sprache in Deutschland, 8 vols. (Stuttgart: Klett-Cotta, 1974-1997) vol. II: 672-725; and cf. Nicolai Rubinstein, "The History of the Word Politicus in EarlyModern Europe," in Pagden (ed.), Languages of Political Theory, 41-56.
} 
their politics is not the single family but rather a large gathering of many households into one civic unit. In line with Burgersdijk's textbook on politica, the De la Courts insist that one household, "consisting of a man, woman, children, servants and maids ... cannot be said to be a Political State", since a single household will never be able to fulfil the principal purpose of civil society, the establishment of order to avoid internal violence and the defence against any external aggression. ${ }^{60}$ For the De la Courts, quantity is an essential criterion for the establishment of a commonwealth. Only an assembly of at least thirty or forty thousand males who convene to establish mutual peace and defence deserves the name of a political state that can be expected to last. This number of thirty or forty thousand men roughly corresponds to the brothers' primary empirical source of inspiration, the larger seventeenth-century Holland cities, like Leiden, which contained a comparable male adult population. ${ }^{61}$ These Dutch urban polities form the central frame of reference for the analysis of citizenship in the work of the De la Courts. "All Inhabitants of a City constitute together truly a Political or Civic body", ${ }^{2}$ and this focus on the city as the essence of politics means that the countryside, and thereby agriculture and ownership of land, play no particular role in the brothers' political thought. This entails a significant difference from the Aristotelian embrace of rural property, especially in the work of Harrington who asserted that "agriculture is the bread of the nation". ${ }^{63}$ In clear contrast, for the De la Courts republican politics are all about being a member of an urban community.

Citizenship in the early modern cities in the Netherlands was a formal, juridical category that separated the poorters, the burghers of a town who enjoyed citizenship rights, from those inhabitants without such rights and from foreigners. ${ }^{64}$ The privileges connected to citizenship included

${ }^{60}$ Politike Weeg-schaal I.I.4, p. 24-25: "Een huisgezin sterk hondert menschen, en bestaande uit man, vrouw, kinderen, dienstknechten en maagden ... kan niet werden gezegt te weezen een Politiken Staat." Cf. Burgersdijk, Idea oeconomicae et politicae II.I.2-3, p. $3^{2-33}$.

${ }^{61}$ On seventeenth-century Dutch urban demographics, see Israel, Dutch Republic, 621, and cf. the more cautious estimate of Leiden's population in Dirk Jaap Noordam, "Demografische ontwikkelingen," in Groenveld (ed.), Leiden, 43-53.

${ }_{22}$ Sinryke Fabulen, 351: "Ende oovermits alle de Ingeseetenen eener Stad te saamen, waarelik een Politik ofte Borgerlik lighaam uit maaken."

${ }_{3}$ Harrington, Oceana, 197.

${ }^{64}$ See Maarten Prak, "Burghers, Citizens and Popular Politics in the Dutch Republic," Eighteenth-Century Studies 30, 4 (1997), 443-448; and Erika Kuijpers and Maarten Prak, "Burger, ingezetene, vreemdeling: burgerschap in Amsterdam in de $17^{\mathrm{e}}$ en $18^{\mathrm{e}}$ eeuw," in Kloek and Tilmans (eds.), Burger, 113-132. Cf. for the case of Leiden: Annie Versprille, "Het 
jurisdictional protection outside the city gates, the possibility to engage in certain occupations organized in guilds or to profit from the local social institutions, and, theoretically at least, the participation in urban government. One became poorter by birth or through marriage, or, as in the case of Pieter de la Court sr., by buying the poorterrecht. In addition to a juridical category citizenship also pertained to a social and economic category, which distinguished relatively rich from poor immigrants who could not afford to become a citizen. In Leiden, citizenship was relatively easy to obtain because it was cheap: during the 1650 on and 1660 , the Leiden poorterrecht sold at only a tenth of the price asked in Holland's main metropolis, Amsterdam. ${ }^{6}$ However, Leiden maintained a formal distinction between such paid citizenship and the 'complete right' obtained by birth. An immigrant who had bought his rights had to wait for seven years to become accepted as a full citizen with the same status as the native population. ${ }^{66}$ In theory, by then he was formally entitled to partake in local government, but in practice immigrants and their offspring were excluded from the higher echelons of the Leiden magistracy for generations.

The brothers De la Court, facing this practice, repeatedly criticized these obstructions to the acquisition of full citizenship. The partial poorterrecht purchased by newcomers, their argument goes, "would change into an idle, powerless term if over time all the advantages ... would be separated from it". ${ }^{67}$ To counter this deflation of the value of citizenship, "one should grant all foreigners who want to come to live in the Cities as much freedom as the other old inhabitants" ${ }^{68}$ In other words, the De la Courts proposed the abolition of any formal juridical distinction between new and old poorters by "granting the Citizens uniform Freedom and Right" ${ }^{69}$ This argument for a policy of open citizenship is substantiated by a number of moves. First of all, the brothers insist that biblical morality calls for hospitality towards immigrants, confirmed as well by

\footnotetext{
Leidse poorterschap," Leids Jaarboekje 36 (1944), 76-100. On the practice and theory of citizenship in England, see Phil Withington, The Politics of Commonwealth. Citizens and Freemen in Early Modern England (Cambridge: Cambridge University Press, 2005).

${ }_{6}$ Versprille, "Leidse poorterschap," 80; Kuijpers and Prak, "Burger," 121.

66 Versprille, "Leidse poorterschap," 81-82.

${ }_{7}$ Welvaren 48, p. 111: "Maer wie siet niet, dat het poorter-reght in een ijdele kraghteloosen name soude veranderen, als men aldus met der tijd alle voordeelen, die ijder poorter daer aen pleegh te mogen koppelen, daer van soude scheiden."

68 Politike Discoursen I.I.1, p. 3: “... zoo behoordemen alle vremdelingen die in de Steeden willen komen woonen, zoo veel vryheids als den anderen oude ingezeetenen te geeven."

${ }^{69}$ Welvaren 2, p. 7: “... den Borgeren eenparige Vrijdom en Reght van alles toestonden."
} 
the classical examples of inclusive citizenship in Athens and Rome. ${ }^{70}$ Following Machiavelli, who repudiated the policy of Sparta of excluding foreigners from civil military service, these references to classical examples of immigration had been a commonplace element of many reason of state treatises that championed the admittance of foreigners as a means to further the greatness of the polity. ${ }^{71}$ The De la Courts adopted this claim for the Dutch context, in particular in connection with their plea for comprehensive religious toleration (see chapter 5 below).

Apart from this assertion that a policy of inclusive citizenship enhances the general interest of society, the brothers De la Court also proposed a second argument in favour of free immigration in terms of natural right. This argument follows partly Grotius's justification of "the right of perpetual cohabitation" for persecuted foreigners who "submit to the Government" of their new home..$^{72}$ The De la Courts develop this Grotian notion in a fable that tells of a group of water birds who seek refuge on an island. After an initial welcome, the native bird population imposes discriminatory regulations upon the water birds, who complain in reply that "against the right of nature and of birth, you call our Children and Grandchildren Foreigners in their own Patria", a verdict that amounts to a "civil death" ${ }^{73}$ The fable serves as an evocative illustration to the claim that the willingness to immigrate reveals that newcomers have tacitly consented with the social contract of the civil society in which they settle. Therefore these newcomers should be granted the same means for their self-preservation as the native population:

It is and remains true that all Inhabitants who have or desire to obtain a permanent residence in this Country are to that extent no foreigners, but Compatriots, and that they should be permitted to the necessary common provisions as much as the old Citizens, since they do not need those less but more. ${ }^{74}$

$7^{70}$ Politike Discoursen I.I.7, p. 63-65, with exempla taken from Thucydides, Xenophon, Plutarch, Cicero, and Lucretius.

${ }^{71}$ Cf. Machiavelli, Discorsi I.6, II.3.

${ }^{2}$ Grotius, Rights of War and Peace II.II.16, p. 85.

${ }_{73}$ Politike Weeg-schaal III.II.4, p. 631-632: “... teegen het regt der nature en geboorte, heet gy onse Kinderen en Kindskinderen in haar eige Patria, Vaderland ofte Geboorteplaats, Vremdelingen ... deese civile dood." The same fable is included in Sinryke Fabulen, 121-126.

${ }^{74}$ Aanwysing I.15, p. 69-70: "Soo is en blijft waarhaftig, dat alle Ingesetenen die hier te Lande een vaste woonplaatse hebben, of begeren te nemen, voor soo veel gene vreemdelingen, maar Landsaaten zijn, ende tot de noodsaaklijke gemeene leevensmiddelen soo wel als de oude Borgers behooren toegelaaten te werden; naademaal sy die niet min maar meer behoeven." 
The De la Courts thus take up Grotius' justification of the right of cohabitation, but turn it into a more fundamental defence of not only the right to settle, but also the right to partake in all social and economic exchanges. This plea for equal economic opportunities involves in particular a strong denunciation of the policy of the Dutch guilds, which excluded non-citizens from the exercise of certain professions (see further chapter 4 below).

The brothers' plea for the abolition of the jurisdictional barriers between natives and newcomers entails a relatively broad conception of citizenship, clearly critical of the restrictive reality in Leiden and elsewhere. Nevertheless, this appeal for hospitality and equal opportunity does not entail the claim that any individual should be considered a full citizen. In particular, one fundamental condition distinguishes those who are capable of actually performing the rights and duties connected to citizenship: the condition of independence in a profoundly hierarchical society.

Seventeenth-century Dutch characterizations of the societas civilis presupposed the active role of its members in a range of ordered communities that together constituted the urban political space. ${ }^{75}$ The fundamental unit of this communal life was the household. As the physician Johan van Beverwijck noted it in Ciceronian vein in his 1639 treatise Van de wtnementheyt des vrouwelicken geslachts ["On the Excellence of the Female Sex"], the family is "the fountain and source" of all authority in which "the first principle of a town and thus the seed of a common state" rests. ${ }^{76} \mathrm{~A}$ similar view was popularized in the widely read manual for a prosperous family life, Jacob Cats's Houwelick ["Marriage"]. Cats's influential work offered its readers a range of moralistic instructions in verse about the four seasons of a female life, from the spring of the bride to the winter of the widow. All culminated in wedlock, described by Cats as "a smithy of men, a foundation of cities, and a nursery of high government". ${ }^{77}$ Women were supposed to perform an exemplary role in taking care of their homes and families. Such 'paragons of virtue' were epitomized in a range of artistic representations of the private life of the household versus the public

\footnotetext{
75 Cf. Marijke Meijer Drees, “'Burgerlijke' zeventiende eeuwse literatuur,” in Kloek and Tilmans (eds.), Burger, 133-153, esp. 144.

${ }^{76}$ Quoted in Simon Schama, The Embarrassment of Riches. An Interpretation of Dutch Culture in the Golden Age (London: Collins, 1987), 386. Cf. Cicero, De officiis I.XVII.54.

77 Jacob Cats, Houwelick, dat is: het gansche beleyt des echten-staets (1625), in Alle de werken van Jacob Cats, ed. W.N. Wolterink, 2 vols. (Dordrecht: J.P. Revers, 1880), vol. I: 253: “... de staet des huwelicx is een smisse van menschen, een grontsteen van steden, en een queeckerye van hooge regeeringe."
} 
life outdoors. ${ }^{7}$ Yet outside the private sphere, male superiority remained largely unquestioned. As 'Father Cats' stated: "The man practices the country's law, the wife the man's will". ${ }^{79}$

This characterization of paternal authority in politics reflected the patriarchal character of seventeenth-century Dutch society. Public life was handled by the male representatives of large elite families, who, linked together through lineage and strategic alliances, constituted the urban councils and the boards of the chartered companies for overseas trade. As Julia Adams has argued, this patrimonial governance was an important factor in the gradual formation of the Dutch Republic as a world power, contributing to the establishment of what she calls a 'Familial State' ${ }^{80}$ This concept clearly entails more than a historical abstraction, for the familial dimensions of politics were echoed in the prevalent political discourse of the time. The writings of the brothers De la Court aptly reveal this language in claims such as "political Rulers are very well called Fathers and the Subjects their Children", or "the Country is an Orphan and the Rulers are the Guardians of that Orphan". ${ }^{81}$

A significant result of this patriarchal emphasis was the idea that women are by nature dependent on their male representatives. As the argument of the De la Courts goes, "all submission originates through lack of power and knowledge, and such lack of power manifests itself fully with Women, since the passions of fear, fright, and sadness seem to be larger, and judgment smaller, in them than in men". Women are for the De la Courts neither able to master their passionate condition, nor to take care of themselves and their offspring without male assistance, and "thus the Domination by Men over Women and Children seems to follow clearly". ${ }^{82}$ The De la Courts conclude that women cannot participate independently in the public life of the community, they cannot speak for

${ }^{78}$ See Wayne E. Franits, Paragons of Virtue. Women and Domesticity in SeventeenthCentury Dutch Art (Cambridge etc.: Cambridge University Press, 1993).

${ }_{79}$ Cats, Houwelick, 283: "De man betracht de wet des lants, Het wijf den wille van de mans."

${ }^{80}$ Julia Adams, The Familial State. Ruling Families and Merchant Capitalism in Early Modern Europe (Ithaca and London: Cornell University Press, 2005).

${ }^{81}$ Aanwysing I.24, p. 118: “... politike Regeerders seer wel Vaders, ende de Onderdaanen haare Kinderen genaamd werden.” Ibidem III.6, p. 495: “... dat het Land een Wees-kind is, en dat de Regeerders zijnde de Voogden van dat Wees-kind.”

${ }^{82}$ Politike Weeg-schaal III.I.1, p. 520: “... alle onderdaanigheit ontstaat door gebrek van magt, en kennisse. Welk gebrek van magt zig allesins openbaart in de Vrouwluiden, om dat de passien van vreese, schrik en droefheit, grooter in haar, en het oordeel minder, als in de mannen schijnt te wesen ... Zulks de Opperhoofdigheit der Mannen, boven de Vrouwen, en Kinderen hier uit klaarlik schijnt te volgen." 
themselves and must be represented by their male superiors. This was a fairly standard view: in theory seventeenth-century Dutch poorterrecht did not make any differentiation on gender grounds, but in practice women were excluded from most civic offices because of their condition of dependence. ${ }^{83}$ For the De la Courts, as for most of their contemporaries, full citizenship was in all aspects implicitly confined to independent men. $^{84}$

\section{The Might \& Right of the Independent Householder}

The brothers' conception of citizenship, then, centres on the male householder who represents his family outside the private realm in the higher strata of the urban society. Dutch cities such as Leiden comprised various gebuyrten or self-installed small neighbourhoods meant to advance the "good peace and civic unity" within the city through the informal settlement of conflict and the organization of communal festivities. ${ }^{85}$ On a more general level, the cities in the Dutch Republic were subdivided into a number of districts that organized the civic militias, or schutterijen. These militias, according to a Leiden statute, ought to protect the "good citizens and inhabitants of this city against all attack, both wanton and otherwise" ${ }^{86}$ The members of Leiden's militias were recruited from poorters and regular inhabitants alike, yet only those men who were settled as independent householders, who practised a certified profession and who were wealthy enough to pay for their own armour, roughly one in every eight male adults, qualified. To serve in the militia was therefore considered a highly honourable task, an essential fulfilment of one's civic duties in the service of the city. ${ }^{87}$

\footnotetext{
${ }^{83}$ See Kuijpers and Prak, "Burger," 123. Cf. for the juridical status of women Donald Haks, Huwelijk en gezin in Holland in de $17^{e}$ en $18^{e}$ eeuw (Utrecht: HES, 1985), 153-154.

${ }^{84} \mathrm{Cf}$. for an exceptional defence of gender equality in this period Siep Stuurman, François Poulain de la Barre and the Invention of Modern Equality (Cambridge, Mass.: Harvard University Press, 2004).

${ }_{5}^{85}$ Quoted in Herman Roodenburg, "Naar een etnografie van de vroegmoderne stad: De 'gebuyrten' in Leiden en Den Haag," in Peter te Boekhorst, Peter Burke and Willem Frijhoff, Cultuur en maatschappij in Nederland 1500-1850: Een historisch-antropologisch perspectief (Meppel etc: Boom, 1992), 219-243, 239: "goede vrede ende burgerlijcke eenigheyt". See also Ronald Sluijter and Ariadne Schmidt, "Sociale verhoudingen en maatschappelijke zorg," in Groenveld (ed.), Leiden, 109-125.

${ }_{86}$ Quoted in Paul Knevel, Burgers in het geweer. De schutterijen in Holland, 1550-1700 (Hilversum: Verloren, 1994), 216: "goede burgeren ende innewoonderen deser stede jegens alle overval, moetwille ende andersints."

${ }^{87}$ Ibidem, 189-190, 200-201. Cf. also the oath for new Leiden poorters quoted in Versprille, "Leidse poorterschap," 96.
} 
In the thought of the brothers De la Court, this urban reality of civic military service attains a distinctive Machiavellian dimension. Directly echoing Machiavelli's dismissal of mercenary armies, the De la Courts argue that "it is better to use in War one's own Subjects than foreign Soldiers". Foreign mercenaries "only serve for money and without love" and hence they do not fight to defend their own liberty, but only to indulge in licentiousness. ${ }^{88}$ With a reference to the same historical episodes as in Machiavelli, the De la Courts insist that "it is most advisable to instruct one's own people in arms, for they are loyal and willing to protect their own goods, wife, and children". ${ }^{89}$ Civic militias that fight in self-defence are therefore a crucial element of a successful commonwealth, for "truly, one becomes very strong when one dares to be his own Master and when the Inhabitants start to know the powers of a People that wants to fight for its Liberty"..$^{\circ 0}$ This assumption is modelled on the experience of a range of republican city-states that preserved their independence for centuries thanks to their arme proprie, from the German free imperial cities and the Swiss cantons to Dalmatian Ragusa and the town of Lucca. De la Court insists that the Dutch Republic also owed its independence from Spain to the patriotic struggle of its people, "especially many prudent Inhabitants, being in trade for years", who fought to safeguard their liberty and commercially attained riches..$^{91}$

With this remark, De la Court establishes a direct connection between mercantile wealth and military civic duty. In line with contemporary practice, he argues that only the rich should be trained in the defence of the state, for they have something to loose and therefore will "serve loyally without payment to protect a lawful Government, as well as their beloved Freedom and all other private Goods, firmly against internal and external violence". The poor, in contrast, should only be allowed to enter

${ }^{88}$ Politike Discoursen I.III.18, p. 297: "Het is beeter sijn eige Onderdaanen, als vremde Krijgs-luiden, in den Oorlog te gebruiken ... vermits sy alleen om geld, en sonder liefde dienen." Cf. Niccoló Machiavelli, Il Principe, ed. Giorgio Inglese (Turin: Einaudi, 1995) XII.5-6, p. 79-8o: "Le mercenarie e ausiliarie sono utile e pericolose ... La cagione di questo è che le non hanno altro amore né altra cagione che le tenga in campo che un poco di stipendio." See also Idem, Discorsi I.43.

${ }^{89}$ Politike Discoursen I.II.31, p. 196: “... sijn eigen volk in waapenen te oeffenen is geraadsaamst: want die sijn getrou, en gewillig om haar eigen goed, bloed, wijf, en kinderen, te beschermen."

90 Aanwysing II.15, p. 370: "Voorwaar dus sterk werd men, als men sijn eigen Meester derfd weesen; ende wanneer de Inwoonders beginnen te kennen de kragten eens Volks dat voor sijne Vryheid vegten wil."

${ }^{91}$ Ibidem II.12, p. 333-334: “... als meede insonderheid veele voorsigtige van ouds koophandel drijvende Ingeseetenen." 
the armed forces in times of war, at a small reward and under the command of "trustful rich Citizens as Officers" so as to prevent them from rebellion..$^{22}$ De la Court thus makes a crucial distinction on the basis of wealth between those who can be expected to defend the government in power, and the poor who should be kept under close control given their unreliability and seditiousness. This is an important move because it involves a direct repudiation of Pocock's interpretation of the early-modern republican tradition. For Pocock, militant virtù was intrinsically linked to landed property. He therefore suggested that it should not be surprising that, in his reading, "Pieter de la Court ... does not seem to have thought his description of a republic of trade called for any account of how the ownership of arms was related to the ownership of property". ${ }^{93}$ Yet as the material discussed here clearly indicates, De la Court did argue that because of their commercial riches, the wealthy in a republic of trade are competent to bear arms and to defend the country's liberty. However, this mercantile military service is fundamentally different from the Machiavellian expansionist virtù that Pocock assumed to be the paradigmatic republican case. For De la Court, merchants will only take up their arms in defence, never for the sake of territorial expansion. "We are by nature Merchants who cannot be turned into Military servants", so he proclaims: ${ }^{4}$ a citizen of a commercial republic will protect his liberty and wealth if necessary, but he always prefers profitable peace over costly war.

De la Court's claim that only the wealthy can be considered capable to serve in the civic militia and thus fulfil the prime civic duty of the defence of the commonwealth entails a significant restriction of the concept of citizenship in line with economic criteria. This restriction, by which not only women but also all dependent males are excluded from full citizenship, becomes particularly evident in the context of the ultimate characteristic of the true citizen, the right to partake in the political decision -making of the community. In a key passage of the Politike Weeg-schaal, revised after his brother's death, De la Court asserts that the governing

\footnotetext{
${ }^{92}$ Ibidem II.15, p. 377-378: “... souden de rijke Inwoonders sonder soldye getrouwelik dienen om eene wettige Regeeringe, neevens haare dierbaare Vryheid, en alle andere particuliere Goederen, standvastelik teegen in- en uitheems geweld te beschermen: de arme Ingesetenen soude men by Oorlogstijden in geringe soldye neemen, ende die dus de genegentheid, alsmeede de kragt om oproer te maaken beneemen konnen, als men haar geene dan vertrouwde rijke Borgers tot Officieren gaf."

93 Pocock, "Patriotism and Politeness," 8.

${ }_{94}$ Aanwysing II.4, p. 255: “... soo sijn wy van naatuuren Koopluiden, die in geene Krijgsknegten veranderd konnen werden."
} 
assembly in the ideal republican polity should consist of "all the Inhabitants of the Country who can be presumed to have sufficient power and knowledge to take care of their own welfare". This assertion implies that all those members of society who live in a condition of dependence cannot be considered capable to master and know themselves and therefore they should not participate in public politics. Women, children, and servants in a household who depend on the pater familias "should for lack of power be excluded ... since they have to pay obedience to their Parents, Husbands, Masters or Lords, and therefore they cannot vote freely". Moreover, newcomers who do not master the local language should equally be prevented from partaking in political debate since they lack "sufficient knowledge of the interest of the Republic" - an important limitation to the De la Courts' appeal for open citizenship..$^{95} \mathrm{~A}$ final category of persons who do not qualify as full citizens are those inhabitants who work for wages and rely on their masters for their income and reputation. Following the example of Venice, where the economically dependent were not included among the citizenry, ${ }^{96}$ De la Court emphasizes that

all dumb, deaf, infamous, and poor people who live of alms or in relief houses, should be excluded, as well as all others who have practised in a certain amount of time any craft or who have worked as day labourers in someone's service ... Since it must be presumed that this happened due to destitution, it must also be presumed that they lacked sufficient knowledge for government. ${ }^{97}$

In other words, De la Court viewed dependency as a sign of incapacity to govern oneself, and hence incapacity to govern the community. Public

${ }_{95}$ Politike Weeg-schaal III.III.5, p. 662: “... een Vergaaderinge, bestaande uit alle de Ingeseetenen des Lands, die gepresumeerd konnen werden magts en kennisse genoeg te hebben, om hun eigen welvaaren te versorgen ... Ten eersten, weegens gebrek van magt, moesten werden buiten geslooten, alle Onmondigen, Vrouwluiden, en Dieners, als aan haare Ouders, Eegade, en Meesters ofte Heeren gehoorsaamheid schuldig zijnde. En dienvolgende niet vryelik moogende stemmen. Ten tweeden, moesten werden buiten geslooten alle vreemdelingen die niet seekeren bepaalden tijd, noodig om genoegsaame kennise van het interest deeser Republike te verkrijgen, onder die regeering hadden gewoont."

${ }_{96}^{6}$ Ibidem II.IV.11, p. 417-418, with an overview of the population of Venice taken from Francesco Sansovino, Le cose meravigliose dell'inclita città di Venezia. Riformate, accomodate, e grandemente ampliate da Leonico Goldioni (1603, facs. ed. Napoli: Liguori, 2003).

${ }_{97}$ Ibidem III.III.5, p. 662-663: "Ten derden, moesten werden buiten geslooten, alle stommen, dooven, infamen, en arme luiden van aalmissen ofte in Godshuisen leevende als meede alle anderen, die binnen seekeren tijd van jaaren, eenig ambagt hadden gedaan, ofte om een dagloon gewrogt in iemands dienst, hoedanig die zoude mogen weesen; vermits het selven moet werden gepresumeert te geschieden, uit behoeftigheid; moet ook werden gepresumeert, de noodige kennisse tot de Regeeringe te ontbreeken." 
performance and active participation in political decision-making require the ability to speak freely and knowingly without any constraint, and this quality is unattainable for those in a condition of dependence. A central asset that distinguishes active citizens from their passive fellow residents is therefore the issue of proper speech, the rhetorical capacity to speak truthfully in public by mastering free republican parrhèsia. The implicit message that underlies the De la Courts' conception of citizenship is the suggestion that only those capable of performing the same rhetoric as they can be expected to speak frankly in public and thus pass the test of being a true citizen. ${ }^{8}$ Those unable to speak the truth should be considered incapable of any political say. The assumption is that their voices are heard through their husbands and masters who represent their interests in public.

Autonomy, being one's own master and sui iuris, is for the De la Courts the key principle that enables men to enjoy their civic rights and perform their civic duties. All those who live in a condition of dependence women, children, servants, the poor, the destitute and the ignorant - cannot enjoy these rights, nor perform these duties, and therefore they are not considered full citizens. The brothers' conception of citizenship is relatively comprehensive for its criticism of Dutch exclusivist practice and its subsequent plea to abolish the existing juridical discrimination between full poorters and newly arrived citizens. Nonetheless, their idea of what constitutes a citizen remains within the narrow Aristotelian boundaries that dominated seventeenth-century theory and practice, even among 'radical' contemporary circles like the Levellers in England or the spinozists in the Dutch Republic. ${ }^{99}$ For instance, Van den Enden, Spinoza's Latin teacher, unequivocally equated citizens with independent males, ${ }^{100}$ while Spinoza employed the very same categories of exclusion as De la Court. ${ }^{101}$ For some historians this might be a reason to criticize

$9^{8}$ See for a more extensive discussion my "Mercury's Two Faces. Commercial Candour as the Key to Capability in the Dutch Golden Age," in Hartman et al. (eds.), Public Offices, Personal Demands, 150-173.

99 See the discussion of the Levellers in David Wootton, "Leveller Democracy and the Puritan Revolution," in Burns and Goldie (eds.), Cambridge History of Political Thought, 412-442: 429-434. On the practice of being an independent citizen, cf. Steven Shapin, $A$ Social History of Truth. Civility and Science in Seventeenth-Century England (Chicago and London: The University of Chicago Press, 1994), 355-407.

${ }_{100}$ Van den Enden, Kort Verhael, 50; and Idem, Vrije politijke stellingen, 179-180.

${ }^{101}$ Spinoza, Tractatus Politicus VI.11, VIII.14, and esp. XI.3-4, p. 442: “... peregrinos secludam, qui sub alterius imperio esse censentur ... mulieres et servos secluderem, qui in potestate virorum et dominorum, ac etiam liberos et pupillos, quamdiu sub potestate 
Spinoza for such a "moment of theoretical inconsistency" that would have impeded him from "putting democracy into practice", but this, needless to say, is a highly anachronistic (and thereby in itself inconsistent) criticism. ${ }^{102}$ Instead, it makes more sense to stress that seventeenth-century republicanism, unlike the modern idea of democracy, was not based on any concept of the intrinsic equality of all people, but only of the equality of all citizens. This fundamental difference should not be underestimated. It shows that it can be problematic to link Spinoza and the De la Courts directly to the "egalitarian tendency" that was to characterize later ages. ${ }^{103}$ Moreover, it reveals an important aspect of early-modern republican ideology that is often overlooked by its current advocates: for its emphasis on the active dominating citizen over the passive dominated individual might be particularly difficult to reconcile with the challenges of modern society. ${ }^{104}$

\section{The Ethics of Self-Interest}

\section{The Two Guises of Self-Love: Eerzucht vs. Heerszucht}

To summarize, civil society originates through a contract between natural men, who thereby turn themselves into citizens and, as independent householders, serve in the defence of the commonwealth and participate in its government. Yet these citizens remain human, enslaved by the fundamental passion of self-love. Is there room for civic morality if citizens will always pursue their deepest instinct of self-preservation, even at the cost of others? This section analyzes the way in which the brothers De la Court tackle this fundamental question. Their moral thought, which involves a significant reinterpretation of Ciceronian ethics, embraces well-understood self-interest as the essence of civil behaviour.

parentum et tutorum sunt ... secluderentur qui ob crimen aut aliquod turpe vitae genus infames sunt." Cf. Jaap Kerkhoven, Spinoza's clausules aangaande uitsluiting van politieke rechten in hun maatschappelijke context. Mededelingen vanwege het Spinozahuis 63 (Delft: Eburon, 1991), esp. 4-5.

${ }^{102}$ Hans Bödeker, "Debating the respublica mixta: German and Dutch Political Discourses around 1700," in Van Gelderen and Skinner (eds.), Republicanism I, 219-246: 228.

${ }^{103}$ Cf. Israel, Radical Enlightenment, 22; and Idem, "Intellectual Origins," 8-9.

${ }^{104}$ On the aristocratic tendencies of early-modern republicanism, see John P. McCormick, Machiavellian Democracy (Cambridge: Cambridge University Press, 2011), 8-11. 
This account forms one of the main pillars of their anti-monarchical and largely secular appeal for the rule of law. ${ }^{105}$

As I have argued in the previous chapter, the brothers De la Court highlight the passionate nature of mankind, a position that merges the rhetorical emphasis on the role of the passions in human speech with Cartesian and Augustinian notions of the way in which our conduct is motivated by the passions. The approach of the De la Courts is particularly close to the contemporary emphasis in French Augustinianism on self-love as the prime human characteristic. Like Jean-François Senault's De l'usage des passions, they begin with the premise that self-love is "the largest and lengthiest Passion by which all People are to a small or large extent captured", ${ }^{106}$ it is "the true origin of all human actions, either good or evil". ${ }^{107}$ This assertion involves the further claim that this central passion of self-love appears in two different ways, either as a moderate virtue or as an excessive vice. Whereas an excess of self-love reveals itself in lust for power and licentiousness, "well-founded Self-love is the root of all laudable outward deeds", ${ }^{108}$ for such true self-love urges humans to preserve themselves and to take care for their nearest family and friends. Loving oneself in a sincere way opens the way to loving "lesser miserable People, out of consideration of common Humanity". Positive self-love thus leads to the love of one's neighbour and of the community of common citizens, the fatherland, and the entire human race:

Since it is necessary that Humans must love above all firstly themselves, and then the ones of their Home, and all the Inhabitants of the Fatherland because they are a part of it, yes that they also must love sincerely the strangest People like they love themselves and those of their Home ... therefore those People, who are in such a way their own Friends that they are at the same time Friends of all the world, are the ones whom God almighty will crown here or hereafter with his Blessing. For this is God's Will, the order of Nature. ${ }^{109}$

${ }^{105}$ This section builds upon my "From the Passion of Self-Love to the Virtue of SelfInterest: The Republican Morals of the Brothers De la Court,"European Review of History 17 , 1 (2010), 75-92.

${ }_{106}$ Sinryke Fabulen, 642: “... de Passien van al te groote Liefde die wy ons selven toe draagen, de aller-grootste ende de allerlangst duurende Passie is, waar meede alle Menschen meer ofte min bevangen zijn."

${ }^{107}$ Politike Weeg-schaal I.I.1, p. 13: "eigen liefde is de waaragtige oorsprong van alle menschelike, 't zy goede, 't zy quade actien."

${ }^{108}$ Welvaren 6, p. 13: “... welgegronde Eige liefde is de wortel van alle lofwaerdige uijterlijcke daden."

${ }^{109}$ Sinryke Fabulen, 130-131: "Ende eindelik aan mindere ellendige Menschen, uit ooverdenkinge der gemeene Menschelikheid ... Derhalven noodsaakelijk zijnde, dat de 
True self-love, in short, fulfils the divine ordainment of the human condition: a claim that distantly echoes Augustine's "brief and true definition of virtue" as "an order of love", by which "someone who loves God does not err in loving himself". ${ }^{10}$

This characterization of self-love as the basis of sociability and charity entails a fairly conventional Christian reading of stoic ethics, in particular of Cicero - a reading exemplified by Augustine, Senault and, in the seven-

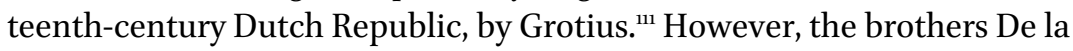
Court clearly depart from both the Grotian analysis of self-love and selfpreservation in terms of natural right and the Augustinian emphasis on divine grace to overcome amour-propre. Their differentiation between true and false self-love involves a distinctive rereading of Cicero that eventually amounts to a largely secular, republican interpretation of the diverse guises of passionate human behaviour.

The contours of this interpretation stem from the stoic repudiation of personal ambition in Cicero's De officiis, probably the most influential classical treatise in the early-modern period. ${ }^{112}$ For Cicero, ambition, defined as the desire for glory, was the human passion that most endangered the virtue of justice, for "the higher a man's ambition, the more easily he is tempted to acts of injustice by his desire for fame". Cicero maintained that such a desire for fame generally reveals itself in the desire to rule over others, the desire "for making oneself king even in the midst of a free people; and anything more atrocious or repulsive than such a passion cannot be conceived". ${ }^{13}$ In the Augustinian tradition, this categorical rejection of ambition was not primarily interpreted as a criticism of the lust for political power, but rather as an exposure of human sinfulness

Menschen voor allen eerst sig selfs, ende daar na die van haaren Huise, ende alle de Ingeseetenen haares Vaaderlands, om dat sy daar van een deel zijn, lief moeten hebben, jaa dat sy ook de allervreemdste Menschen ongeveinsdelik, gelijk sy sig selfs, ende die van haaren Huise beminnen, moeten lief hebben, naar geraade, dat yder van dien haar bestaat; Soo zijn die Menschen, welke soodanig haare eigene Vrienden zijn, dat sy met eenen Vrienden van alle de weereld blijven, die geene, welke God almagtig hier ofte hier naa, met sijnen Seegen kroonen sal. Want dit is Goodes Wil, ende by gevolge, de ordre der Natuure."

${ }^{110}$ Augustine, Van de stadt Godts, trans. Johannes Fenacolius, 5 vols. (Amsterdam, 1646) $\mathrm{XV.22,} \mathrm{vol.} \mathrm{IV,} \mathrm{fol.} \mathrm{18:} \mathrm{"...} \mathrm{een} \mathrm{korte} \mathrm{en} \mathrm{waerachtige} \mathrm{beschrijvinghe} \mathrm{des} \mathrm{deuchts} \mathrm{zy,} \mathrm{nameli-}$ jcke dat deselfde zy een ordre der liefde." Ibidem XIX.14, vol. V, fol. 18: "... die gene niet en doolt in het lief hebben van sich selven, die Godt lief heeft." Pieter de la Court van der Voort owned a copy of this Dutch translation of Augustine's De civitate Dei: Library, fol. 10.

${ }^{111}$ Cf. esp. Grotius, Commentary, Prolegomena, p. 21, 41.

${ }^{112}$ On the impact of Cicero's De officiis in seventeenth-century Europe, see Peter N. Miller, Defining the Common Good. Empire, Religion and Philosophy in Eighteenth-Century Britain (Cambridge: Cambridge University Press, 1994), 21-87.

${ }^{113}$ Cicero, De officiis, trans. Miller, I.XIX.65, p. 67; III.VIII.36, p. 303. 
when devoid of divine grace. As Senault argued evocatively, the "disordered affection" of amour-propre involves "the death of families, the ruin of States, and the loss of Religion ... For from this disordered Love originate three other loves that poison all souls and that banish all virtues from the earth: the first is the Love of Beauty, which is called Immoderation, the second is Love of Riches, which is called Avarice, and the third is Love of Glory, which is called Ambition". ${ }^{114}$ For Senault, immoderate love of oneself leads to the worship of false appearances instead of true adoration of God.

The brothers De la Court read Cicero's criticism of personal ambition in a different way by establishing a fundamental distinction between eerzucht, the desire for honour, and heerszucht, the desire to rule. This distinction comes down to the claim that sincere self-love causes people to want to be praised and admired. Although such desire for praise might seem nothing but vanity, "in fact it is a large incentive to speed diligently during the short and fragile life of Humanity to perform something laudable". ${ }^{115}$ The desire for honour drives people to fulfil their human potential in a way that does not harm others, thereby gaining esteem through which their self-love is gratified. True self-love as expressed in eerzucht therefore enables people to understand that they have to perform deeds by which they themselves and the rest of society have something to gain.

The De la Courts are acutely aware that such personal ambition can also corrupt, "for many People, driven by a wrong Desire for honour, otherwise called Imperiousness, desire to rise above those who are truly equal to them". ${ }^{16}$ Here the excess of self-love reveals itself, "the false self-love, and bad Desire for honour", which changes eerzucht, the incentive to be praised, into heerszucht, the ambition to rule. ${ }^{117}$ This Tacitean cupido

\footnotetext{
${ }^{114}$ Senault, De l'usage des passions, 235: "Je concluds donc, que cette affection desordonnée est la mort des familles, la ruine des Estats, \& la perte de la Religion ... Car de cet Amour desreglé, naissent trois autres amours, qui empoisonnent toutes les ames, \& qui bannissent toutes les vertus de la terre; Le premier est l'Amour de la Beauté, qu'on appelle Incontinence; Le second est l'Amour des Richesses, qu'on appele Avarice; Le troisiesme est l'Amour de la Gloire, qu'on appele Ambition."

${ }_{15}$ Sinryke Fabulen, 86-87: “... in der daad eene groote aanprikkeling, om geduurende het kort ende broos leeven der selven Menschen, sig met allen yver te spoeden, ietwes loofwaardigs te verrigten."

${ }^{116}$ Ibidem: “... om dat seer veele Menschen door eene verkeerde Eergierigheid, anders gesegt Heerssugt, gedreeven werdende, sig booven de geenen, die haar waarelik gelijk zijn, willen verheffen."

${ }^{117}$ Ibidem, 124: “... eene verkeerde eigen-selfs liefde, ende quaade Eergierigheid.”
} 
dominandi is not only "the most ardent of all our Passions", 18 it is also the most dangerous, since unlike true self-love, the lust for power necessarily jeopardizes others. Heerszucht is a characteristic of those who have become so powerful that they are exclusively lauded and never admonished and thus indulge in all the bodily lusts and other passionate excesses of human nature. Such people are in fact "so Bestial that they think that they are not connected to the common human society and esteem no one but themselves ... and also love no one else" ${ }^{119}$ This false form of self-love is especially characteristic to monarchs, whose relentless pursuit of power remains unchecked by any fear or discipline. Living "like wild men in statu naturali", virtually outside of the ordered civil society, they "do everything that they desire without minding praise or punishment" ${ }^{120}$ Accordingly, "the desire for honour, which is for all common men a very sharp incentive to all virtues, stimulates [these monarchs] to all the villainies concessa pudet ire via civemque videri, Lucan - that are forbidden for the Citizens". ${ }^{121}$ This revealing quote from Lucan's Pharsalia shows that for the De la Courts the figure of Caesar, the commonplace incarnation of tyranny, also embodies false self-love, the ruthless desire to rule. They consider false self-love to be essentially a monarchical passion, contrasted by the sincere republican ambition to be honoured by one's fellow citizens.

\section{Appropriating the Language of Interest}

The focus of this account of the political consequences of the passions is sharpened by the distinctly modern vocabulary that the De la Courts

${ }^{118}$ Ibidem, 385: “... dat de Heerssugt ofte Begeerte, om oover andere Menschen te heerssen, de vierigste van alle onse Herts togten is." The saying is a literal translation from Tacitus, Annals XV.53, p. 300: "cupido dominandi cunctis adfectibus flagrantior est", also quoted in slightly different versions in Politike Weeg-schaal, I.I.18, p. 98; I.III.1, p. 234; and Aanwysing, "Voor-reeden," sig. ${ }^{* * *} 2$.

${ }^{119}$ Ibidem, 131: “... Menschen, die soo Beestagtig zijn, dat sy meenende aan de gemeene menschelijke maatschappie niet verbonden te zijn, niemand dan sig selfs agten, ende by gevolge sig daar van af scheidende, oopenbaarelik voor niemand als voor haar eigen selfs sorgen, ende ook niemand anders lief hebben."

${ }_{120}$ Politike Discoursen II.VI.5, p. 184: "Ten is dan niet vreemd indien de Vorsten, en andere Overheeden, of seer Magtigen, deese vreese ontwassen zijnde, ende gelijk als wilde menschen in statu naturali, of puris naturalibus, alles doen wat hun lust, sonder op lof, of straf, te passen."

${ }^{121}$ Ibidem II.V.11, p. 146: "Jaa dat meer is, den Souveraine Heeren ontbreekt niet alleen dese toom, om haar van de ondeugd te wederhouden; maar de eergierigheid, die den gemeene menschen een seer scherp prikkel tot alle deugden is, prikkel haar tot alle schelm-stukken, concessa pudet ire via, civemque videri, Lucan., die den Borgers verbooden zijn." The quote is from Lucan, Pharsalia II, v. 446. 
employ to characterize human self-love, either true or false: the vocabulary of 'interest'. The use of 'interest' as a political and moral concept originated in the Ricordi of the Florentine republican Francesco Guicciardini, written around 1530 and first published in 1576. Guicciardini argued that human nature is essentially selfish, yet as long as this egotism encourages people to maintain their honour and perform laudable deeds, it can be justifiable. Confronted with the question of how individual gains can be reconciled with the common good, Guicciardini asserted that searching for one's self-interest is positive as long as it pursues aristocratic honour instead of pecuniary advantage as a means to further the public interest. ${ }^{122}$ Guicciardini mainatined that such an interesse dello stato or general interest of the state exists, in particular in international affairs. The relations between different polities, like the intersubjective behaviour of self-interested individuals, can be explained trough a rational calculation of every state's needs and priorities. ${ }^{123}$

This language of interesse, or as it soon was to be called, ragion di stato became widely diffused in late sixteenth-century Italy and subsequently spread over the rest of Europe. ${ }^{124}$ Yet from the outset, it was a highly ambiguous language. As in Montaigne, it contained a strong tension between the notion of "l'interest commun", or the common good, and the notion of "l'interest et passion privée", the disruptive passion of selflove. ${ }^{125}$ This tension, overlooked by Albert Hirschmann in his classic The Passions and the Interests, would characterize the use of the term

${ }^{122}$ Cf. Francesco Guicciardini, Ricordi, ed. Emilio Pasquini (Milan: Garzanti, 1999), 218, p. 254: "Quegli uomini conducono bene le cose loro in questo mondo, che hanno sempre innanzi agli occhi lo interesse proprio, e tutte le azione sue misurano con questo fine. Ma la fallacia è in quegli che non conoscono bene quale sia lo interesse sua, cioè che reputano che sempre consista in qualche comodo pecuniario più che nell'onore, nel sapere mantenersi la riputazione e il buono nome."

${ }^{123}$ For an analysis of the language of 'interest' in Guicciardini and in subsequent natural law theory, see the highly informative article by Lionel A. McKenzie, "Natural Right and the Emergence of the Idea of Interest in Early Modern Political Thought: Francesco Guicciardini and Jean de Silhon," History of European Ideas 2, 4 (1981), 277-298. For Guicciardini's political thought in general, see Viroli, From Politics to Reason of State, 178-200.

${ }^{124}$ For lucid overviews of the emergence and spread of the language of 'interest' and reason of state, see Tuck, Philosophy and Government, 38-119; Viroli, From Politics to Reason of State, 238-280; and for the later seventeenth and eighteenth century, Pierre Force, SelfInterest Before Adam Smith. A Genealogy of Economic Science (Cambridge: Cambridge University Press, 2003).

${ }^{125}$ Michel de Montaigne, Les Essais, ed. Jean Balsamo et al. ([Paris]: Gallimard, 2007) III.1, p. 833,843 . 
throughout the seventeenth century. ${ }^{126}$ In some writings of the reason of state tradition, 'interest' was equated with the indisputably main concern of a polity, independent of personal opinion or the character of the sovereign. This most roaring and resounding phrasing of this view came in the motto of the Duke of Rohan's De l'interest des princes et des etats de la chrestienté (1639), which exclaimed that "Les Princes commandent aux peuples, et l'interest commande aux Princes", for "Le Prince se peut tromper, son Conseil peut estre corrompu; mais l'interest seul ne peut jamais manquer" ${ }^{127}$ However, not all seventeenth-century authors were so emphatic about the positively unfailing character of interest. For a sceptical Tacitist like Virgilio Malvezzi, who wrote in the same years as Rohan, it should rather "be noted that men will always be more moved by private interest then by public utility" and thus, to their own disadvantage, even prefer to be "a slave and rich then to be poor and free". ${ }^{28}$

By employing the language of 'interest', the brothers De la Court position their writings in this many-sided approach to the connections between self-interested personal behaviour and the needs and concerns of statecraft. Their use of the concept entails a double move that aptly reveals the ambiguities that characterized the term. First of all, the De la Courts appropriate the abovementioned phrase of the Duke of Rohan to claim that there exists a normative common interest such as the interest of Holland', a general political standard that can be scrutinized empirically. Given that "all Peoples of Europe, like the Spanish, the Italians and

${ }^{126}$ Albert O. Hirschmann, The Passions and the Interests. Political Arguments for Capitalism before its Triumph (Princeton: Princeton University Press, 1977). Hirschmann maintains that 'interest' as a concept arose in opposition to the predominant view on the passions, as a countervailing tamer of man's unruly passionate behaviour. However, this interpretation is too narrow, for it overlooks the seventeenth-century notion of 'interest' as a fashionable designation of human self-love, the major human passion. Cf. Force, SelfInterest, 142-144; and Ernst Wolfgang Orth "Interesse," in Geschichtliche Grundbegriffe, vol. III, 305-365: 319-320, with evidence of 'interest' used as a synonym for either proprio amor (Ignatius de Loyola), l'amour naturel de soi-même (Fénelon), or l'âme de l'amour propre (La Rochefoucauld).

${ }^{127}$ Henri de Rohan, De l'interest des princes et Estats de la Chrestienté, in [Rohan], Le parfait Capitane ... augmenté d'un traicté: de l'interest des princes et Estats de la Chrestienté ([Leiden], 1648), 100-101. See also J.H.M. Salmon, "Rohan and Interest of State," in Roman Schnur (ed.), Staatsräson. Studien zur Geschichte eines politischen Begriffs (Berlin: Duncker \& Humblot, 1975), 121-140.

${ }_{128}$ Virgilio Malvezzi, Discorsi sopra Cornelio Tacito (Venice, 1635), 91: "E quì è da notare, che gli huomini si muoveranno sempre più per privato interesse, che per publica utilità: $\mathrm{e}$ che ogn'uno ha più caro d'esser servo, e ricco, che povero, e libero." Pieter de la Court van der Voort owned this edition: Library, fol. 19. For Malvezzi's life and works, see Rodolfo Brändli, Virgilio Malvezzi. Politico e moralista (PhD thesis Basel, 1964). 
the French, express this thing with the word Interest", De la Court assumes that this remarkable linguistic agreement proves the universal validity of the concept. ${ }^{129}$ Such an analysis of politics in terms of interest, originally a commercial term, implies that political behaviour is somehow comparable to commercial exchanges that follow the laws of predictability..$^{130}$ Perhaps the most insistent example of this attitude came from the sharp, chameleonic pen of the English pamphleteer Marchamont Nedham, whose short 1659 treatise Interest will not Lie opens with the claim:

That if you can apprehend wherein a man's Interest to any particular Game on foot doth consist, you may surely know, if the man be prudent, whereabout to have him, that is, how to judge of his designe: For, which way soever you foresee his Interest doth in prudence dispose him, that way (provided he be so wise as to understand his own Concernment) he will be sure to go, and so his Interest (provided also, that in your calculation thereof you be not mistaken) will not lie to you, it will not deceive you in your judgement concerning the mans Intents and Proceedings. ${ }^{1{ }^{11}}$

Accordingly, this first use of the vocabulary of interest involves the pretension that it is possible to achieve certain, calculable knowledge of politics and morals.

On the other hand, the De la Courts also adopt the second meaning of the term, the assertion that the unsettling passion of self-love expresses itself primarily in the desire to further one's self-interest at the cost of the common good. They frequently employ typical proverbs from Italian scepticist reason of state, like Il proprio interesse è una grande bestia, che comanda a tutti and Piú pesa una oncia d'util proprio, che cento libre di stato, to confirm this point: ${ }^{12}$ for "who would bring water to his

${ }^{129}$ Aanwysing I.1, p. 1: "En dewijl meest alle Volkeren van Europa, als Spanjaarden, Italianen en Francoisen, deese saak uitdrukken met den woorde Interest."

${ }^{130}$ See McKenzie, "Natural Right," 279, 294, note 1. For 'interest' as a commercial term, see e.g. Politike Weeg-schaal I.IV.2, p. 297; II.IV.10-11; III.II.4, p. 621; III.III.2, p. 651.

${ }^{131}$ Marchamont Nedham, Interest will not Lie. Or, A View of England's True Interest (London, 1659), 3. On Nedham, see esp. Blair Worden, "Marchamont Nedham and the Beginnings of English Republicanism, 1649-1656," in Wootton (ed.), Republicanism; 45-81; Idem, Literature and Politics in Cromwellian England. John Milton, Andrew Marvell, Marchamont Nedham (Oxford: Oxford University Press, 2007); and Rahe, Against Throne and Altar, 179-244. More on the language of 'interest' in seventeenth-century England in J.A.W. Gunn, “'Interest Will Not Lie': A Seventeenth-Century Political Maxim,” Journal of the History of Ideas 29, 4 (1968), 551-564.

${ }^{132}$ E.g. in Welvaren, p. 119, 138. Cf. on this language of interest in early-modern republican Lucca, Peter N. Miller, "Stoics Who Sing: Lessons in Citizenship from Early Modern Lucca," The Historical Journal 44 (2001), 313-339. For the appropriation of this language in the Dutch political debate, see Tieranny van eigenbaat (1679). Toneel als wapen tegen Oranje, ed. Tanja Holzhey and Kornee van der Haven (Zoeterwoude: Astraea, 2008). 
neighbour's house when his own is on fire", when it is also possible "to set another's house to fire to warm oneself by its coals"? ${ }^{133}$ In the development of the brothers' œuvre, this second usage of 'interest' increasingly replaces the term 'self-love'. Eventually this development results in the claim that "Self-Interest is the most prominent, if not the only, objective of all human deeds", and that "the inclination to hunt for one's own Interest ... is typical of Humanity, and therefore it can and will last for eternity" ${ }^{134}$ The work of the brothers De la Court is thus characterized by the same tension that pervaded the general use of the language of 'interest' throughout the seventeenth century: human behaviour is dominated by the unruly passion of self-interest, often without regard for the common good, yet at the same time society at large has one general interest that is independent of the whims of personal human conduct.

The core of the moral thought of the brothers De la Court involves an attempt to alleviate this very tension. ${ }^{135}$ At the basis of this attempt lies their reappraisal of Ciceronian ambition as the true, sincere form of selflove, the desire to be praised by one's fellow citizens for the performance of laudable deeds. This characterization leads to the acknowledgment that self-interest does not necessarily run counter to the common good: as Guicciardini had argued before, the desire for honour is justifiable if it brings about behaviour that serves society at large. This form of self-interest involves the ability to connect "private advantage wisely with the common welfare", the ability to understand how individual gains can be linked to the public good. ${ }^{136}$ As such it is the direct opposite of "self-interest wrongly understood", ${ }^{137}$ the pursuit of self-love without attention to the

${ }_{133}$ Politike Weeg-schaal I.I.1, p. 15: "Een ander mans huis aan brand steeken om sig by te koolen te warmen." II.I.4, p. 325: “(piu pesa un oncia d'util proprio, che cento libre di stato) wie brengd water aan zijn buyrmans huis als eigen in brand staat?" III.III.1, p. 639: "Niemand hinkt van het seer eens ander mans, in wiens oore is te snijden als in een vilthoed, en wiens huis men ligtelik aan brande steekt, als men sig by de koolen sal konnen warmen."

${ }^{134}$ Sinryke Fabulen, 192: “... Eigen-Interest is het voornaamste, indien niet eenigste oogwit aller menschelike uitwerkingen.” Ibidem, 441: “... de geneegenheid om sijn eigen Interest te bejaagen ... aan den Menschen eigen is, ende dienvolgende in der eewigheid duuren kan, ofte sal." Cf. the similar usage of the term in Aitzema, Historie of verhael, vol. III, 841: “... zijnde natuerlick dat een yeder jaeght en janckt na 't geen hy bemindt, ende een yeder bemindt zijn interest."

${ }^{135}$ Cf. for a more extensive analysis with some different accents: Blom, Morality and Causality, esp. 174-180; and Idem, "Burger en Belang."

${ }^{136}$ Politike Discoursen II.IV.7, p. 50: "Ende dat eigen voordeel, dus wyselik met het gemeen welvaaren verknogt zijnde.”

${ }^{137}$ Sinryke fabulen, 126: “... een verkeerd begreepen eigen Inter-esse.” Cf. Harvey C. Mansfield, "Self-Interest Rightly Understood," Political Theory 23, 1 (1995), 48-66. 
general interest. A proper acknowledgment of the connection between personal advantage and the common good implies that self-interest as the defining characteristic of human behaviour can be reconciled with the indisputable interest of society at large.

This doctrine of well-understood self-interest entails a crucial departure from the classical view that the quest for personal advantage should be subordinated to the common good. As, for example, Senault insisted, "Justice requires that a good Citizen prefers the public interest over the one of his house ... When Self-love only induces a man to work for his pleasure or for his glory, it constitutes the end of all his actions". ${ }^{138}$ Yet for the brothers De la Court, the pursuit of glory does not necessarily entail the demise of civic virtue. Given the predominance of the passion of selflove, this is in fact the only way to achieve any form of virtuous behaviour. According to their logic, an individual who subordinates his personal interest unconditionally to the common good is a mere chimera. For "who can be his guarantee that he will remain steady in his virtue and not fall into vice?"139 Someone who pretends to search for the public interest without regard for his personal advantage should not be trusted, for such a pretension merely reveals that he has misunderstood his self-interest - and thus is enslaved by the worst of all passions, the desire to rule. By contrast, "the virtue of an Honest man and of a Good Politician entails that he prudently connects his own advantage to the Common one. And this is quite doable, for the path of Virtue is not so unfruitful for the Politicians as has been wailed sometimes". ${ }^{140}$ The brothers De la Court see no reason to be overly sceptical about the political consequences of the human condition, as long as the key passion of self-love manifests itself as the virtue of selfinterest well-understood.

\section{The Politics of the Passions}

The crucial means to overcome the corruptive potential of the passion of self-love lies in the disciplinary framework that is established with the creation of civil society. As the argument of the De la Courts goes:

\footnotetext{
${ }^{138}$ Senault, De l'usage des passions, 232-233: “La Justice veut qu'un bon Citoyen prefere l'interest public à celuy de sa maison ... Cependant l'Amour propre ne fait travailler un homme, que pur son plaisir ou pour sa gloire, il le constitüe la fin de toutes ses actions."

139 Politike Discoursen I.II.5, p. 105-106: "Wie kan sijn borge zijn, dat hy daar in bestendig sal blijven, ende niet tot ondeugd sal vervallen?"

${ }^{140}$ Welvaren 61, p. 141: "En voorwaer hier in bestaet de deughd van een Eerlijck man en van een Goed Politijck, dat hij voorsightighlijck sijn eigen voordeel aen 't Gemeen koppelt. En het is wel doenelijck, want de wegh des Deughds soo onvrughtbaer niet en is voor de Politijcquen, als sij wel werd uijtgekreten."
} 
If all Citizenship and Assembly would not be generated and caused by mutual fear, then Man would, like Children, desire to obtain anything that he likes or that pleases him. So he refrains from doing that, not paying for his lusts, through the fear that Discipline and Reason install in him. ${ }^{141}$

The bridle of discipline, the fear for punishment that regulates a wellordered civil society, thus ensures that the passions intrinsic to human nature are harnessed towards a useful civic purpose. This reformation of manners relies in particular on two central disciplinary factors, education and the rule of law. One of the primary aims of the brothers De la Courts is to demonstrate that in the absence of such a disciplinary framework, that is, in a monarchy, the consequences are disastrous. Meanwhile, their embrace of disciplined civic behaviour involves a distinctive secular appeal for mercantile moderation as the key characteristic of the true citizen.

First of all, the brothers De la Court insist that the passions that define human nature should be disciplined by good civic instruction. This means that parents teach their children "not only to improve through their own experience their passions and judgment, but also to increase that experience wonderfully through studies and knowledge of various Languages and old Histories, and to let them live with all the earlier centuries and far-away Countries". ${ }^{142}$ This typically humanist educational precept, combining historical knowledge with practical experience, leads to knowledge of oneself and the world at large, and thus it teaches people how to take care for themselves without harming others. Yet such civic teaching is not alone sufficient to create true, sincere self-love. Human nature is capricious, and even those who have been raised in virtue may become haughty, pretentious and imperious when praised by others. A further disciplinary means is therefore necessary to counter excessive self-love. This is the corrective framework of the rule of law. In the De la Courts' secular Augustinianism with Hobbesian undertones, human nature always tends to evil unless it is moderated by the rule of law. Hence, "all the laws of a State should be made thus, as if all men were evil, since they will

\footnotetext{
${ }^{141}$ Politike Discoursen II.VI.5, p. 182: "Indien niet alle Burgerschap, en Vergadering, door onderlinge vreese veroorsaakt, en by een gebragt wierd; soo soude de Mensch gelijk de Kinderen, alles wat hem aanstond, of lusten mogte, begeeren te verkrygen; sulks hy sijn lusten niet boetende, het selven naa-laat door de vreese die de Tugt, en de Reeden in hem heeft gebragt."

${ }_{142}$ Politike Weeg-schaal III.I.5, p. 537-538: "Jaa niet alleen door eige ervarentheit haare passien en oordeel te beteren, maar ook door de studien, en kennisse van verscheide Talen, en oude Historien, die ervarentheit wonderlik te vergrooten, en haar te doen leeven met alle de voorgaande eeuwen, en verre-afgelege Landen."
} 
indeed become evil, at least for the largest part, unless they are restrained by the fear for punishment. And therefore the saying goes: La fame \& la povertà fa gli homini [sic] industriosi \& le leggi gli fanno boni". ${ }^{43}$ This Machiavellian phrase makes clear that without the rule of law, the passions that define human nature can never be harnessed towards a virtuous purpose. In the absence of education and disciplinary laws, the human condition reveals its most ardent and most dangerous characteristic: the desire for domination.

The republican logic of the brothers De la Court presents the pernicious life at a monarchical court as the exemplary locus where such undisciplined conduct thrives. Princes and courtiers, who have not grown up amongst equals, have never experienced the temperance of "knowledge with knowledge, or passion with passion". Therefore they have never learned "that they are human". Instead, being the victim of the envy and distrust of their parents and competitors, princes and courtiers have been educated in such a way "that all good knowledge and virtues are extinguished in them, and at the contrary all ignorance and vice as much as possible cultivated". This is the reason that the "children of Monarchs" who are about to ascend to supremacy (the allusion to the young Prince of Orange is clear) indulge in "childish ostentation" and all kinds of bodily lusts. ${ }^{144}$ The De la Courts appropriate numerous sources to prove this assumption, from a range of disenchanted sententiae taken from Tacitus's description of Tiberius and his adopted son Germanicus, to a critical version of Philippe de Commines's judgment on Louis XI, and finally, an adaptation of the anti-monarchical satire of the prime contemporary Tacitist, Boccalini. ${ }^{145}$ In revising the Politike Weeg-schaal, De la Court

${ }^{143}$ Politike Discoursen II.VI.20, p. 252: "Ende dien volgende soo is ook klaar dat alle wetten van een Staat soodanig behoorden gemaakt te zijn, als of alle menschen boos-aardig waaren, dewijl sy inder daad boosaardig staan te werden, ten minsten voor het meeste gedeelte, ten zy sy door de vreese van straf, werden weederhouden. En daarom segt het spreek-woord: La fame \& la povertà, fa gli homini industriosi, \& le leggi gli fanno boni." The phrase is from Machiavelli, Discorsi I.3, p. 16.

${ }^{144}$ Politike Weeg-schaal I.I.12, p. 57: “... in hare kindsheid nooit omgaan met kinderen haars gelijk, die zonder geveinstheid, kennisse met kennisse, ofte passie, met passie, opscharpende ofte tegengaande haar zouden leeren dat zy menschen zijn ... dat alle goede kennisse en deugden in haar werden uitgebluscht, en ter contrarie alle onweetenheid en ondeugt, zoo veel mogelik aangequeeckt ... En waar om de kinderen der Monarchen, voorneementlik dien de Hoogheid booven 't hoofd hangt, zig dus vermaaken met kinderlike pronkery."

${ }^{145}$ Ibidem, 57-64, quoting e.g. Tacitus, Annals II.42 an II.82; a passage in translation from Philippe de Commines, Mémoires (1524-28, published in Leiden by Elzevier in 1648), and a fable from Boccalini's Ragguagli, vol. I., ragg. 56, p. 203-204. 
included yet another, less obvious source to substantiate his claims: the Histoire du Roy Henry le Grand by Hardouin de Péréfixe, the former tutor of Louis XIV, published by Elzevier in 1661 when the king took over governmental powers after the death of Mazarin. This work was essentially a mirror of princes in the form of a historical tract that praised the rule of Henry IV, but De la Court deployed it as an insider's account that revealed the baseness of monarchical education. ${ }^{146}$

The second means to harness true self-love, discipline by the rule of law, is equally absent at a royal court. The brothers De la Court insist that the fundamental mistake of the adherents of monarchy is their assumption that kings will be more virtuous than other mortals, though they are merely all too human. This claim is again illustrated by the sententiae of Tacitus and Lucan. ${ }^{147}$ "Living above all Laws and political orders", kings will always follow their passions instead of reason, not bridled by any disciplining. ${ }^{148}$ They do instil fear among their subjects, but of the wrong kind, since it makes people afraid of uttering the truth and instead conduces them to indulge in sycophancy. Subjected to the dissimulative speech of courtiers who change their vices into virtues, kings will in fact lead the unhappiest life, destitute of true Ciceronian amicitia and "living without hearing truth or seeing Friends". ${ }^{49}$ Again, in his revision of the Politike Weeg-schaal De la Court employed a typical mirror of princes as incontestable evidence for this statement: the Idea de un príncipe politico christiano by the Spanish diplomat Fajardo. Fajardo warned his royal audience for the ministers who keep the king "diverted with songs and entertainments, intending to occupy his ears while the murmurings and the voices of truth and exposure cannot enter". ${ }^{\circ}$ All such

${ }^{146}$ Ibidem, 59-62, 66-69, with a translation and a long quote in French from Hardouin de Péréfixe, Histoire du Roy Henry le Grand (Amsterdam: Elzevier, 1661), 458-461, 513-517. The library of Pieter de la Court van der Voort had a copy of this edition: Library, fol. $3^{2}$.

${ }^{147}$ Ibidem I.I.10, p. 47, quoting from Lucan, Pharsalia VIII, v. 452: "Nil pudet adsuetos sceptris" and Tacitus, Annals II.42: "Regibus aequa, nedum infima insolita sunt."

${ }^{148}$ Ibidem I.II.1, p. 172: “... dat de Monarchen boven alle Wetten en politike ordren zijnde, moeten werden geconsidereerd altijds hare passien en driften des bloeds, schoon genoomen die klaarelik ten verderve hunner Onderdaanen strekken, te zullen involgen."

${ }^{149}$ Ibidem I.I.21, p. 105: "De beste geboore Heeren zijn ongelukkige menschen, en Regeerders; levende zonder waarheid te hooren, ofte Vrienden te zien."

${ }^{150}$ Ibidem, 108-110, quoting from Fajardo, Idea principis christiano-politici, symb. XIII. I have used the contemporary Spanish edition: Idea de un príncipe político christiano representada en cien empresas (Amsterdam, 1661), 116: “... le traen divertido con músicas, y entretenimientos, procurando tener ocupadas sus orejas, sin que puedan entrar por ellas los susurros de la murmuración y las vozes de la verdad, y del desengaño." For an analysis of this passage see Romanoski, Tacitus Emblematicus, 409-412. 
dissimulation necessarily results in the corruption that is intrinsic to life at court where the worst of human passions thrive - a claim based on yet another insider's account of courtly behaviour, the Traicté de la Cour, ou instructions des courtesans by the French diplomat Eustache du Refuge, first published in 1616 and again by Elzevier in several editions in the 1640s and 1650 s. $^{15^{1}}$ This manual for courtiers was meant to instruct its readers how to comply with the conventions at court, paying ample attention to the importance of speech, the uses of flattery and how to moderate the passions. ${ }^{15^{2}}$ Yet the De la Courts merely employ it for its statement "que la Cour est une grande Putain, laquelle corompt [sic] le plus entiers et le plus chastes" - a phrase quoted repeatedly (and with noticeable gusto) throughout the brothers' works. ${ }^{153}$ They thus turn a warning to courtiers into a fundamental critique of courtiers, which entails an obvious rhetorical move: if even the insiders of monarchical life such as Péréfixe, Fajardo, and Du Refuge maintain that the court corrupts, then no adherent of the monarchical principle can possibly refute this claim.

In this way, the brothers De la Court employ numerous sources from the inner circles of the European royal courts to argue that under monarchical rule the passions intrinsic to the human condition will necessarily corrupt true human self-love. They stress empathically that all the passionate defects of a monarch "as far as he is Human" will not only spread among those at his court, but also among all his subjects. ${ }^{154}$ The result is that especially "in old absolutist Monarchies, public shame is not at all bothered about, and self-interest is absolutely shamelessly pursued ...

${ }^{151}$ Elzevier published three Latin editions of the second part of the work in 1642, 1644 and 1649, and a French version in 1656: Eustache du Refuge, Traicté de la Cour, ou instruction des courtisans (Amsterdam, 1656). For the influence of this treatise on English views on courtly conduct and civility, see Markku Peltonen, The Duel in Early Modern England. Civility, Politeness and Honour (Cambridge: Cambridge University Press, 2003), 28-31.

${ }^{152}$ See Du Refuge, Traicté I.II-V, p. 15-17 (on courtly 'civilité' and 'affabilité'), I.XXXIV, p. 149-156, II.VI-VII, p. 193-201, II.XII, p. 224-228 (on dissimulation and flattery), I.XIIIXXVI, p. 44-117 (on how the passions "aveuglent du tout nostre entendement" and on the "Usage de la cognoissance des passions, \& les moyens de les moderer, en nous, \& en autruy").

${ }^{153}$ Ibidem II.V p. 189, quoted in Politike Weeg-schaal I.I.21, p. 110; I.I.27, p. 132 ("te Hoof, in dat Groot Bordeel"); Politike Discoursen II.V.12, p. 150 ("het Hof, sïnde een groote hoer"); and Sinryke Fabulen, 194.

${ }_{154}$ Politike Weeg-schaal I.I.14, p. 82: "Eindelik is onder Monarchale regeeringen een zeer groot quaat, dat de gebreeken des Souverains, voor zo veel hy een Mensch is, terstont werden naargevolgt van zijn Hovelingen, en van daar zig over het geheele Land verspreiden." Cf. Machiavelli, Discorsi III.29. 
without taking any notice of shame or decency". ${ }^{55}$ A society ruled by a monarch is no true civil society where the passionate excesses of the human condition are bridled, but rather "a country that will be filled with Fops, Dancers, Players, Cursers, Fornicators, Hunters, Gluttons, and Boozers $\& c .{ }^{\prime 156}$

These moral concerns about the corruptive potential of immoderate self-love might not seem particularly exceptional, given that the basic conventions of Christian humanism shared the same emphasis on education and discipline vis-à-vis human sinfulness. However, it is important to note that the thought of the brothers De la Court relies neither on a providential divine framework nor on the cultivation of inner virtue to overcome the excesses of human nature. Instead, their approach to the role of the passions in politics centres on a largely secular notion of the rule of law, indebted to, in particular, Machiavelli. Echoing the Discorsi, the De la Courts insist that

in this evil world nothing more detrimental to human society can be thought of than to envisage, when establishing a government and making Laws, how prudent, virtuous and impassionate Rulers and Subjects ought to be inclined ... On the contrary, nothing more beneficial can be thought of than to consider well how cunning, evil, lecherous and fully passionate people will be inclined, so that politics and laws are established in such a way that the evil Rulers and Subjects will always be obliged to behave well. ${ }^{57}$

This key passage asserts that politics is not about the elusive concept of virtue but about the harsh reality of the passions, the self-loving nature of rulers and ruled alike. As a result, the conventional emphasis on a range of Ciceronian and Christian virtues, from fortitude to magnanimity, largely disappears from sight in the work of the De la Courts. Their account

155 Ibidem I.I.27, p. 133: “... in oude absolute Monarchien, wert die publike schande, gantsch niet geagt, en eigen intrest, allesins onbeschaamdelik voortgezet, ... zonder eenigzins op eenige schanden, ofte welvoegentheit, te passen."

${ }^{156}$ Ibidem I.I.14, p. 82-83: “... en niet vreemt is dat een land wert vervult, met Pronkerts, Dansers, Speelers, Vloekers, Hoereerders, Jaagers, Vreeters, en Zuipers, \&c. alles naar dat de Heer zelfs sig geneegen toont te weesen."

${ }^{157}$ Ibidem I.II.1, p. 173: “... in deeze booze werelt, voor de societeit der menschen niet schaadeliker kann werden bedagt, dan dat men, in het formeeren der regeeringe en maaken van wetten, voor oogen hebbe, hoe voorzigtige, duegtzame en ongepassioneerde Regeerders en Onderdaanen behoorden gezint te weezen; en dat in zoo een geval, ter contrarie niet heilsaamer kan werden bedagt, dan wel te considereeren, hoe doortrapte, boosaardige, wellustige, en allezins gepassioneerde menschen gezint zijn, op dat de politie en wetten zoodanig werden geformeert, dat de boosaardige Regeerders, en Onderdaanen, altijt genootsaakt werden, zig wel te draagen." Cf. Machiavelli, Discorsi I.3, p. 15: “... è necessario a chi dispone una repubblica ed ordina leggi in quella presupporre tutti gli uomini rei." 
replaces the devotional love of one's neighbour with calculated self-interest, it subordinates the fear for God and the afterlife to the fear for worldly punishment. Significantly, this passage is followed by the remark that such a secular disciplinary framework corresponds among all religions best with Reformed Calvinism. This embrace of a particular creed is thus not the foundation of the analysis, but only a secondary consequence. Moreover, the De la Courts assert "that the external Profession of Religion, whether Jewish or Christian, does not make any change in human nature, and that all People, whether Jewish, Christians or Heathens, are or become very ignorant and evil if they are born in or ascend to such Supremacy that they are not subjected to any laws or punishments". ${ }^{15}$ The universal human condition reveals its darkest side if it remains unrestrained by the rule of law, regardless of confessional particularities.

The secular emphasis of this politics of the passions is particularly important because it points to a significant difference between the thought of the brothers De la Court and contemporary republican ideology in England. As Jonathan Scott has argued convincingly, seventeenthcentury English republicanism primarily involved a religiously inspired reformation of manners. ${ }^{159}$ In particular John Milton and Algernon Sidney continuously connected their criticism of the corrupted Stuart court with the threat of looming religious corruption. For example, Sidney unequivocally equated monarchical tyranny with impiety, "idolatry" and "the destruction of the godly" ${ }^{160}$ while Milton insisted that the execution of Charles I "delivered the Commonwealth from a grievous domination, and religion from a most debasing thraldom". ${ }^{161}$ This emphasis on political theology also explains the remarkable popularity of the model of the Hebrew Republic among seventeenth-century English republicans. ${ }^{162}$ Yet even

${ }^{158}$ Politike Weeg-schaal I.I.33, p. 167-168: “... dat de uiterlike Proffessie van Religie, 't zy Joodse, 't zy Christelike, geen veranderinge brengt in den menscheliken aart, en dat alle Menschen, 't zy Jooden, Christenen of Heydenen, seer onwetende en boosaardig zijn of werden, wanneer sy tot sodanige Hoogheid geboren zijn, ofte stigen; dat sy gansch geen wetten ofte straffen onderworpen zijn."

${ }_{159}$ Scott, Commonwealth Principles, esp. 41-62.

${ }_{160}$ Algernon Sidney, Court Maxims, ed. Hans W. Blom et al. (Cambridge: Cambridge University Press, 1996), 190, 194.

${ }^{161}$ John Milton, Second Defence of the People of England, in Idem, Areopagitica and Other Political Writings (Indianapolis: Liberty Fund, 1999), 315.

${ }^{162}$ See Eric Nelson, The Hebrew Republic. Jewish Sources and the Transformation of European Political Thought (Cambridge, Mass.: Harvard University Press, 2010). For the Dutch context, see also Lea Campos-Boralevi, "Classical Foundational Myths of European Republicanism: The Jewish Commonwealth," in Van Gelderen and Skinner (eds.), Republicanism, vol. I: 247-261. 
though this model was largely developed by Dutch authors, most importantly Petrus Cunaeus, Grotius, and Spinoza, such religious engagement is largely absent from the republican endeavour of the brothers De la Court. Their emphasis on self-interest largely eclipses any notion of Christian virtuousness, and their anti-monarchical criticism consequently lacks the religious connotation of English republicanism. Yet, as the next chapters will continue to argue, this does not mean that the De la Courts are less radical, or 'exclusivist', than their English republican contemporaries. On the contrary: the brothers' anti-monarchism proves to be exceptionally far-reaching and consistent in comparison with other seventeenth-century republicans, while the brothers' religious relativism has equally important consequences for their plea for comprehensive religious toleration.

Overall, the brothers' repudiation of monarchical mores centres on their reappraisal of Ciceronian ambition as the sincere quest for personal honour within the bounds of civic discipline. This particular reading of Cicero, meant to adapt the ethics of honour for an urban society based on commerce, reveals a striking parallel with the archetypical figure in the Dutch Golden Age of the 'wise merchant': the successful entrepreneur who engages in self-interested trade yet, reaping the seeds of a humanist education, proceeds rationally and honestly in public affairs.

\section{REPRESENTING THE Wise Merchant}

\section{Barlaeus on the Mercator Sapiens}

The concept of the 'wise merchant' was coined in a famous speech by the Dutch humanist scholar Caspar Barlaeus. On January 9, 1632, Barlaeus gave a lecture at the opening of the Amsterdam 'Athenaeum Illustre', a college that, in the absence of a local university, offered higher schooling to the city's youth. ${ }^{163}$ The first chairs of the Athenaeum were taken by Barlaeus and his close friend and colleague Gerard Vossius. Addressing the fathers of the young men he was about to teach, the prosperous elite of a city that had become famous for its trade, Barlaeus chose an appropriate topic for his speech: the connection between commerce and the study of philosophy, or, as he called it, the ideal of a mercator

${ }^{163}$ See Dirk van Miert, Illuster onderwijs. Het Amsterdamse Athenaeum in de Gouden Eeuw, 1632-1704 (Amsterdam: Bert Bakker, 2005). 
sapiens. ${ }^{164}$ Barlaeus' main aim was to reveal the value of the time-honoured studia humanitatis for a modern commercial society. His speech clearly manifests a Ciceronian attempt to reconcile the right and the expedient in a world dominated by the pursuit of private gains.

From the start, the lecture reflected the communal concerns of the speaker and his audience, gathered in "this new sanctuary for the Muses". In an opening oration, Barlaeus asked God for wisdom and guidance in civic and commercial affairs, stressing in particular the need to maintain religious concord in the city of Amsterdam. He then continued to request "that those, who have so far followed Mercury, will by now be called candidates for Wisdom; plain but with elegance; striving for money but without detriment for a better motivation, which is science and virtue". ${ }^{165}$ From the opening lines of his speech, Barlaeus thus made an explicit connection between mercantile virtuousness and the challenges of a society characterized by religious diversity. His professed intention "not to condemn but to control the strivings for possessions through the reins of right reason", ${ }^{166}$ indicates that he considered the rational and balanced pursuit of riches essential for the welfare and stability of the commonwealth. Indeed, Barlaeus stressed that the elements of Aristotelian "civil prudence", from experience and ingenuity to judgment and consultation, were also "the very same elements and tasks of commerce". ${ }^{167}$ The merchant who took up these tasks wisely embodied the ideal citizen engaged in the public life of the polity.

At the same time, Barlaeus also revealed his preoccupation that riches and luxury might corrupt Amsterdam's merchants. His aim was thus to

${ }_{164}$ The lecture was published the next year: Caspar Barlaeus, Mercator sapiens, sive oratio de conjungendis mercaturae \& philosophiae studiis (Amsterdam, 1633). For a modern edition with a Dutch translation see Caspar Barlaeus, Mercator sapiens. Oratie gehouden bij de inwijding van de Illustere School te Amsterdam op 9 januari 1632, ed. S. van der Woude (Amsterdam: Universiteitsbibliotheek, 1967). See also the French edition with an extensive introduction by Catherine Secretan (ed.), Le "Marchand philosophe" de Caspar Barlaeus. Un éloge du commerce dans la Hollande du Siècle d'Or (Paris: Honoré Champion, 2002), and the analysis of Barlaeus's speech, with some different accents, in Cook, Matters of Exchange, 68-73.

${ }_{165}$ Barlaeus, Mercator sapiens, 3-4: "Stat supplex civium ordo ... in novo hoc Musarum sacrario ... Da, ut Mercuriales hactenus, jam Sapientiae candidati audiant; parci, sed cum elegantia; pecuniae studiosi, sed sine detrimento melioris studii, hoc est, artium \& virtutis."

${ }^{166}$ Ibidem, 8: “... non ut opum studia damnem, sed rectae rationis sufflamine coërceam.”

${ }^{167}$ Ibidem, 24: "Aristoteles ... Prudentiae civilis administras comitesque facit, Experientiam, Memoriam, Solertiam, Ingenium, Sententiam \& Consolium. At hae ipsissimae sunt mercaturae partes \& oficia." 
"demonstrate with the weighty precepts derived from Philosophy that Wisdom can cure their vices". First of all, he insisted that merchants should not to be avaricious but rather practice moderation and always acquiesce to their position. "Those who strive for immoderate riches", Barlaeus taught his mercantile audience, "will often lose immoderately ... and thus while luxury overthrows some, ambition brings down others if the lust for profit is destitute of and unadvised by the warnings of Prudence". Hence, "not he who owns more, but he who desires less, is rich ... The philosopher calls the soul of man rich and not the moneyboxes, however full those are, for as long as the soul suffers from the lust for money, she is poor. ${ }^{{ }^{668}}$ To overcome the threat of such commercial corruption, Barlaeus put forward his central claim:

Wisdom does not contemn the wealthy but embraces them, under one condition: that they are rich without harm to others, magnificent without luxury, liberal without ostentation, weighty without pedantry, religious without superstition. ${ }^{169}$

Thus Barlaeus sought to justify mercantile enterprise with an account that, explicitly based on Ancient stoicism and in particular on Cicero's De officiis, highlighted the virtuousness of a rational and moderate pursuit of riches in the service of the common good.

As Barlaeus repeatedly stressed in a distinctly Ciceronian vein, honestum, the morally right, cannot be separated from utile, the expedient. ${ }^{170} \mathrm{He}$ continued to stress the practical merits of the wise merchant, his firmness in times of misfortune, the duty to be honest in commercial exchanges, and, in particular, to take care for the "public welfare" as "a man among men, and a citizen among fellow citizens". ${ }^{171}$ This practice of charity and

${ }_{168}$ Ibidem, 13-14: "Sed proprium libet mercantium virtutes expendere, \& depromptis è Philosophia gravibus praeceptis ostendere, quam \& illorum vitiis mederi possit Sapientia ... Qui immodicas opes sectantur, immodicis saepe excidunt ... atque ita dum alios sua luxuria, alios ambitio praecipitat, hos inconsulta ac Prudentiae monitis destituta lucri cupiditas ... Non enim qui plus habet, sed qui minus cupit, dives est ... Philosophus animum hominis divitem appellat, non loculos. Qui quantumvis pleni sint, dummodo pecuniae cupiditate laboret animus, pauper es."

${ }^{169}$ Ibidem, 16: "Sapientia opulentos non fastidit, sed exosculatur unice. Illos nempe, qui locupletes sunt sine ullius injuria, magnifici sini luxu, liberales sine ostentatione, graves sine morositate, religiosi sine superstitione."

${ }^{170}$ Ibidem, 18-19. Cf. the classic discussion of utile and honestum in Cicero, De officiis, esp. II.III.9, III.III.11, III.VIII.35, p. 303: "quod autem bonum, id certe utile; ita, quicquid honestum, id utile."

${ }^{171}$ Barlaeus, Mercator sapiens, 20: “... cum ea lege natus sis, ne publicae saluti officias, \& ut homo de hominibus, civis de concivi bene merearis." 
sociability would be enhanced by the study of both moral and 'speculative' philosophy (i.e. the sciences of geography, biology, astronomy, and meteorology), and by learning the languages and customs of different peoples. Barlaeus thus suggested that commercial wisdom consists to a large extent of the practical application of theoretical knowledge, and that this practical insight is essential for the fulfilment of civic duties. ${ }^{172}$ His panegyric emphasized that with the establishment of the 'Athenaeum Illustre', Amsterdam would obtain the same status as other outstanding centres of trade, learning and civility such as Ancient Athens and Venice: in educating young merchants to become wise, the entire city would flourish. ${ }^{173}$

This carefully constructed plea for the public cultivation of mercantile virtue and insight involved the claim that one specific commercial quality makes the wise merchant in particular apt for performing in public. As Barlaeus argued, this quality stems from the double divinity of "the most ingenuous of the Gods, Mercury", who apart from being the god of commerce was also "the author of wisdom and eloquence". Through incorporating these two faces of both commerce and wise rhetoric, Mercury revealed that "merchants need both wisdom and fluency; the one so that they can discern honest from disgraceful gains, the other in order to commend with the allure of words the goods which they are satisfied to sell". ${ }^{174}$ This suggestion that the ability to discern honesty from dishonesty is related to appealing speech entails a significant parallel between commercial practice and truthful, persuasive rhetoric. As Barlaeus insisted: "A merchant with a sincere and good mind ... distinguishes decent from vicious merchandise, like he distinguishes virtues from vices." ${ }^{175}$ The theoretical and practical upbringing of the wise merchant makes it possible to approach human behaviour as if it were merchandise, to differentiate between virtue and vice on the account of commercial insight into what is good and bad, irrespective of any in utramque partem reasoning. With this argument against both unfair trade and dissimulative

${ }^{172}$ Cf. Jacob Soll, "Accounting for Government: Holland and the Rise of Political Economy in Seventeenth-Century Europe," Journal of Interdisciplinary History 40, 2 (2009), $215^{-238 .}$

${ }^{173}$ Barlaeus, Mercator sapiens, 30-31.

${ }^{174}$ Ibidem, 9-10: “... ingeniosissimum Deorum Mercurium, illum sapientiae ac eloquentiae autorem. Nempe ut doceant, \& sapientia \& facundia opus esse mercantibus; illa, ut quaestum honestum à turpi discernere possint, hac; ut verborum lenocinio commendent eas merces, quas extrudere satagunt."

175 Ibidem, 16: "Erectae \& bonae mentis mercator ... sicut vitiosas merces à probis, ita virtutes a vitiis distinguit." 
speech, Barlaeus asserted that honesty and outspokenness are essentially commercial virtues. It is the wise merchant who masters as no other the proper parrhèsia for entering the marketplace of public political debate, and thus he fulfils the prime prerequisite of a truly civic life.

Barlaeus' inaugural lecture was an important public event, and his portrayal of the mercator sapiens resonated far beyond the walls of the Amsterdam Athenaeum when it was published and translated into Dutch in the following decades. ${ }^{176}$ In general, his attempt to reconcile the vicissitudes of commercial society with the precepts of classical humanism arose from the long-standing mercantile culture of the cities in the Low Countries, which, from the medieval period onwards, resulted in a characteristically urban and commercial approach to civic ethics in which 'the citizen' was at times identified with 'the merchant'. ${ }^{177}$ The speech of Barlaeus evidently stood in this tradition. In particular, his reading of the Ciceronian connection between honestum and utile was part of a more widespread endeavour in the Dutch Golden Age to legitimize the pursuit of commercial gains in light of classical and Christian mistrust of mercantile activity. Aristotle's Politics argued that trade for the sake of the accumulation of wealth is unnatural, a verdict echoed by Cicero in his disapproval of the "vulgarity" of trade..$^{178}$ The Biblical condemnation of usury and worldly riches reinforced this anti-commercial ethics. Accordingly, humanist scholars and clergymen in the Dutch Golden Age struggled with the challenge of how to reconcile this classical and Christian legacy with the commercial realities that defined their society.

An early example of this struggle was the dialogue De Coopman ["The Merchant"], in which the sixteenth-century moralist Dirck Coornhert

${ }^{176}$ The lecture opened the widely circulated collection of Barlaeus's speeches, the Orationum liber (Amsterdam, 1643), which went into three editions and was translated as Oratien, en Blijde inkomst van Maria de Medicis (Amsterdam, 1662). A Dutch translation of the lecture was published separately in 1641: Verstandighe coopman, of Oratie, handelende van de t'samen-voeginghe des koop-handels, ende der philosophie (Enkhuizen, 1641).

${ }^{177}$ See Herman Pleij, "Poorters en burgers in laat-middeleeuwse literaire bronnen," in Kloek and Tilmans (eds.), Burger, 55-79, esp. 56-59. Cf. also Karin Tilmans, "Republican Citizenship and Civic Humanism in the Burgundian-Habsburg Netherlands (1477-1566)," in Van Gelderen and Skinner (eds.), Republicanism, vol. I: 107-125; and Clé Lesger, "Merchants in Charge. The Self-Perception of Amsterdam Merchants, ca. 1550-1700," in Margaret C. Jacob and Catherine Secretan (eds.), The Self-Perception of Early Modern Capitalists (New York: Palgrave MacMillan, 2008), 75-97.

${ }^{178}$ Aristotle, Politica I.9-10 (1257a-1258b); Cicero, De officiis I.XLII.151. 
debated with his interlocutor the need for a range of virtues, most importantly Christian charity, to counter the corruptive effects of trade. ${ }^{179}$ The Calvinist cleric Godefridus Udemans tackled the issue in his widely read treatise 't Geestelyck roervan 't coopmans schip ["The Spiritual Helm of the Merchant's Ship"], which aimed to show "that Commerce is an honest activity, as long as it is pursued in the justice and fear of the Lord" ${ }^{180}$ Udemans reproved Cicero's portrayal of petty trade in De officiis, and in reply argued that commerce is a necessary means to foster the welfare of society and to spread God's word overseas. Yet Udemans then continued with an extensive account of all the devout virtues that the merchant should cultivate - an account that, as Simon Schama has shown in his classic on the subject, The Embarrassment of Riches, left little room for any truly mercantile enterprise. ${ }^{181}$ Meanwhile, at Leiden University, Burgersdijk transmitted the Aristotelian doctrine with the claim that commerce is justifiable, but only if it aims to relieve scarcity, for the mere accumulation of wealth goes against nature. ${ }^{182}$ Other academics such as Boxhorn and Salmasius equally participated in the public debate on the role of commerce, in particular with regard to the pressing issue of usury and the establishment of municipal loan offices. This issue continued to dominate theological and political debate throughout the $1650 \mathrm{~s}$, when one Leiden pamphlet asserted on the basis of a range of classical and Christian sources that usury "is useful for the mutual society and conduct with each other" if compatible with "Christian love", and therefore "founded and based on natural fairness". ${ }^{183}$ Such apologies for mercantile practice were obviously not restricted to the narrow confines of the Dutch Republic. For example, the German academic Johannes Marquardus published a large juridical treatise in 1662 that sought to make commerce salonfähig in the

${ }^{179}$ Dirck Volckertsz Coornhert, De Coopman. Aenwijsende d'oprechte conste om Christelijck ende met eenen gelijcken moede in 't winnen ende verliesen Coophandel te drijven (Norden, 1620).

${ }^{180}$ Godefridus Udemans, 't Geestelyck roer van 't coopmans schip, 3d. ed. (Dordrecht, 1655), sig. *4: "dat de Koopmanschap, is eene eerlijcke handelinge, als die maer gedreven wordt in de gerechtigheyt, ende vreese des Heeren."

${ }^{181}$ Ibidem, 14-61. See Schama, Embarrassment of Riches, 330-331.

${ }^{182}$ Burgersdijk, Idea oeconomicae et politicae I.VIII.16, p. 26: "Mercatura ergo est legitimus acquirendi modus, si adhibeatur ad supplendis nature defectus. At si referatur ad augendam pecuniam, sine aloquo ulteriore fine, jam naturae contraria erit, quia progredietur in infinitum."

${ }^{183}$ Consideratien raeckende 't stuck van leeninge op interest ende panden (Leiden, 1657), sig. A: “... dienstich is tot de onderlinge gemeynschap en hanteringe met malkanderen, welckers handelingen en contracten niet strydigh syn, met de plichten van de Christelycke liefde, en welkce gefundeert en gegrondvest is in de naturele billickheydt." 
Empire. Frequently referring to the Dutch example, including Barlaeus's speech, Marquardus emphasized the public utility of trade, following the adage that "Commerce is not the name of a Vice but of an Office". ${ }^{184}$

Barlaeus's contribution to this debate on the social role of commerce and mercantile wealth stands out for its distinctive humanist use of classical sources, which eclipse the religious emphasis that dominated from Coornhert onwards. Barlaeus did not aim to come to terms with commercial society from a Christian point of view, but rather to turn the icons of humanism, in particular Cicero, into advocates of honourable trade. He took the pursuit of mercantile riches and the accumulation of wealth for granted as unavoidable elements of modern life, not to be curtailed by piety but rather to be mobilized in the service of the common good and the study of the classics. The brothers De la Court continued on this path set out by Barlaeus. On the one hand, they shared a similar emphasis on mercantile moderation and wisdom as essential features of a civic life. On the other, the way in which the De la Courts presented themselves, both in image and in word, reveals that their embrace of riches gradually departed from the classical preoccupation with the corrupting potential of commercial wealth.

\section{Un-courtiers: A Mercantile Reformation of Manners}

It should be stressed that the œuvre of the brothers De la Court does not engage explicitly either with the Aristotelian claim that trade for the sake of the accumulation of riches is unnatural, or with the contemporary debate on the legitimacy of commercial practices such as usury. Instead, their portrayal of what makes a merchant wise involves a clear political move which suggestively contrasts mercantile civic ethics with the base morality of a courtly society. The distinctive reformation of manners that the De la Courts propagate is therefore not directed against the possible excrescences of commerce, but rather against the continuous threat of courtly decadence and dissimulation that corrupt all honour and honesty in commercial affairs. They turn Barlaeus's humanist account of mercantile virtues and honourable trade into a decisively politicized interpretation of true republican citizenship.

${ }^{184}$ Johannes Marquardus, Tractatus politico-juridicus de iure mercatorum et commerciorum singulari (Frankfurt, 1662) I.2, p. 18: "Mercatura non est nomen Vitii sed Officii." Pieter de la Court van der Voort owned a copy of this treatise: see Library, fol. 10. 
One of Barlaeus' main messages was the claim that the pursuit of profit is honourable if it does not give rise to uncivil greed and ostentation. The brothers De la Court adopt this plea for mercantile modesty to their account of the political consequences of self-love. This account reproves "squandering" as "truly a passion that generally belongs to Princes", whose constant exposure to courtly flattery and unbridled power deprives them of self-knowledge and leaves them enslaved by their lusts. In a true civil society, citizens should not try to follow such royal example. Instead, "it is especially for the common Citizens very laudable to lead their live according to the following saying ... A wise man is content with little." ${ }^{{ }^{85}}$ Moderation thus fulfils the civil desire to be praised, while the unrestrained yearning for possessions reveals a greed similar to the desire for domination, as in the imperial devices of plus oultre and semper augustus. ${ }^{186}$ With this juxtaposition of the covetousness of the monarch versus the modesty of the true citizen, the De la Courts give an explicit republican content to Barlaeus's assessment of the poverty of the insatiable soul.

An essential element of such civil moderation is the placid acquiescence with one's social status, a popular theme in seventeenth-century Dutch literature which clearly reflected a widely shared discomfort with the realities of social climbing. ${ }^{187}$ The De la Courts insist that citizens who have successfully obtained an honest way of living should not try to leave this "industrious or careful Civil State" and "commit the stupidity of wanting to rise even higher and imagine to be able to live like Nobles". ${ }^{188}$ Such parvenus merely prove to be driven by false self-love, and "by a too large desire of Honour they dress themselves more splendidly, live in bigger homes and set richer tables than their position or means permit". ${ }^{189}$ This

${ }^{185}$ Politike Discoursen II.VI.15, p. 222, 224-225: “... quist-gierigheid, waarlik een passie die doorgaans in Vorsten is ... Ende ter contrarie is het booven alle, voor den gemeene Borgeren een seer loofwaardige saak sijn leeven naar deese volgende spreek-woorden aen te stellen ... Een wijs mensch, is met weinig te vreeden."

${ }^{186}$ Ibidem II.VI.4, p. 178.

${ }^{187}$ See e.g. Cats, Spiegel III, emblem II, p. 5-6 (on a monkey climbing to the top of a post, thereby revealing his bottom), and emblem VIII, p. 21-23, which concludes saying "Die hooger klimt als hem betaemt/Valt laeger als hy heeft geraemt". Cf. also Vondel, Vorsteliicke warande, fables XXVI, LXIX and XCVIII.

${ }^{188}$ Sinryke Fabulen, 65: “... binnen den arbeidsaamen ofte sorgvuldigen Borgerlijken Stand blijvende ... sy des niet te min alsdan die dwaasheid begaan van nog veel hooger te willen stijgen, ende waanen als Eedelluiden te konnen leeven."

${ }^{189}$ Politike Discoursen II.VI.19, p. 242: “... door te groote begeerte van Eere, sig selven pragtiger kleeden, grooter huis bewoonen, en rijker tafel houden als haar staat of middelen toelaaten." Cf. a similar passage in Sinryke Fabulen, 235-236. 
uncivil pretentiousness is imaginatively ridiculed in a fable that tells of a frog who does not understand the fundamental equality of his species and vaingloriously thinks he is able to grow as large as a cow: blowing himself up to the extreme, the frog finally bursts apart. ${ }^{190}$ The obvious message is that such swollenness strips people of all civil dignity and reduces them to the base level of those who personify monarchical manners: nobles and courtiers.

Another fable evocatively explains this difference between the civility of the modest citizen and the incivility of the courtier. The fable tells of a fly who, while eating "at the most sumptuous tables ... sleeping on purple beds, and kissing there the cheeks of the most beautiful Women", ridicules the hard labour of an ant. The ant then replies with saying that he has carefully amassed enough goods to survive, while the fly will certainly not make it through the winter. In a further clarification, De la Court defines the fly as "a Man who lives splendidly and lecherously, or a Courtier", while the ant personifies "a Man who is humble, diligent and thrifty" ${ }^{191}$ This praise of a modest accumulation of goods as opposed to courtly display makes clear that riches as such are not to be condemned if achieved by honest means. De la Court eulogizes how "most of the Riches of Civil Families in Holland" stem from "thrift and frugality" and the utter renunciation of any luxury. Such praiseworthy conduct stands in direct opposition to the idleness of those who refuse to practise a useful occupation, like commerce, and instead indulge in opulence "in the French way". ${ }^{192}$ As in the fable of the Kingdom of Apes, De la Court thus contrasts Dutch diligence and modesty, the example of mercantile morality, with the ostentation and laziness of the Frenchman, the prototype of courtly corruption.

This preoccupation with the corruptive consequences of luxury was fairly conventional. ${ }^{193}$ However, it is important to stress that the brothers De la Court never rebuke the pursuit of riches. On the contrary: in their commercial logic, wealth generally proves to be the result of sincere selflove and civil ambition. It is therefore not riches that corrupt, but power.

${ }^{190}$ Sinryke Fabulen, 61-66. Cf. Vondel, Vorsteliicke warande, fable XXXIII.

${ }^{191}$ Ibidem, 47-50: “... aan de alderkostelikste tafelen, eet aldaar de lekkerste spijse ... slaap op purperen bedden, ende kus aldaar de wangen der allerschoonste Vrouwen ... een Mensch die pragtig ende wellustig leefd; ofte een Hooveling. Met een MiER, een Mensch, die neederig, arbeid-ende spaarsaam is." Cf. Vondel, Vorsteliicke warande, fables XII and LVII.

${ }^{192}$ Ibidem, 272-273: “... de meeste Rijkdommen van Borgerlijke Familien in Holland, sijnen oorsprong heeft van ... naarstig- en suinigheid ... volgens der Francoisen wijse."

193 Cf. Christopher J. Berry, The Idea of Luxury. A Conceptual and Historical Investigation (Cambridge: Cambridge University Press, 1994), which emphasizes the importance of the 'Dutch example' in the seventeenth century, yet without any discussion of Dutch sources. 
As the brothers argue, "people whose wealth is devoid of power are by most reasons incited to knowledge and virtues and deterred from all evil ... Thus actually not wealth but power and licence are the cause of many evils". ${ }^{194}$ The De la Courts thus adopt Barlaeus's claim that mercantile riches should be appraised if employed for the sake of wisdom and virtue. At the same time, they make an implicit move away from the classical concern that the accumulation of goods will lead to corruption. This concern still haunted Barlaeus's portrayal of the wise merchant. For the De la Courts, in contrast, mercantile wealth gives no reason for anxiety, since the real source of evil is the unrestrained lust for power.

The brothers' gradual departure from the traditional mistrust of the accumulation of riches is revealed by the language in which they portray honourable civil conduct. Barlaeus's humanist vocabulary of the classical virtues of the wise merchant, from piety to prudence, virtually disappears from their writings, while his Ciceronian argument for the overlap between utile and honestum becomes couched in the consciously modern language of 'interest'. This gradual move from virtue to self-interest eventually results in a corresponding shift from the common good to private advantage as the standard of mercantile morality. Like his predecessor Coornhert or his Calvinist contemporary Udemans, Barlaeus primarily emphasized the value of individual commercial activity for society at large, in particular through the practice of charity. Yet in the thought of the De la Courts charity attains a strikingly different connotation. A crucial passage in the Sinryke Fabulen describes charity not primarily as a virtue, but as a passion, a passion that can easily turn into "wrong charity" when directed towards people who indulge in laziness and only hope to profit from the riches of their industrious fellow human beings. ${ }^{195}$ This remarkable change in emphasis shows how the brothers De la Court depart from the late humanist view on riches and poverty as expressed by Barlaeus. In the development of their œuvre, and most strikingly in De la Court's last work, the Sinryke Fabulen, wealth is increasingly identified as a moral value that characterizes the thrifty, the diligent, and the wise. Barlaeus's assertion that "wisdom does not contemn the wealthy but embraces them" thus turns into an account that maligns poverty as a

\footnotetext{
${ }_{194}$ Politike Discoursen II.VI.5, p. 183: "Maar men moet seer wel op-merken dat menschen wiens rijkdom ontbloot is van magt, door de meeste reedenen tot kennissen, en deugden geprikkeld, en van alle boosheeden afgeschrikt werden ... sulks niet eigentlik de rijkdom, maar de magt en licencie, oorsaak veeler boosheeden is."

195 Sinryke Fabulen, 512-514: “... eene verkeerde barmhertigheid.”
} 
result of human weakness and vice. The concerns of late humanism make place for the concerns of commercial enterprise.

A significant result of this line of reasoning is the ensuing claim that commercially attained riches and mercantile rationality and moderation are the essential tokens that distinguish true citizens from their counterparts, the poor and the plush. With conventional scorn for the unruly rabble, the De la Courts insist that poor people, who "have to spend their time in working for their subsistence", lack the education and resources necessary to harness their passions into "the appropriate desire for honour", and hence they lose themselves in wastefulness. The other social pole, the nobility, is equally prone to false self-love:

having banned all discipline, these Lords follow their desires so immoderately that they have run into debt before they realize that their goods are diminishing. And therefore luxury brings about the same among them as need tends to cause among the poor People. ${ }^{196}$

The civic middle group in between these two extremes practices diligence and thrift to preserve and accumulate wealth without lavishness and luxury. These citizens, "who are used to being rich, realize that their treasure ... can be easily lost due to the accidents and evil of the world". To weapon themselves and their offspring against the whims of fortune, they "frugally and diligently take care for their household" and they "raise their children ... in all sciences, arts and virtues" ${ }^{197}$ In short, it is these wise merchants who fulfil the prime criteria of honourable citizenship.

Finally, the De la Courts' adaptation of Barlaeus's portrayal of the wise merchant has important implications for their position in the classical debate on how to reconcile the vita activa in the service of the public good with the vita contemplativa of isolated philosophical inquiry. Barlaeus's

${ }^{196}$ Politike Discoursen II.VI.16, p. 227-229: “En dewijl de arme Luiden haar tijd in 't werken tot haar onderhoud, moeten besteeden, soo gebreekt hun de selve om haar ziele te leeren tugtigen ... de behoorlike eersugt ... alle tugt uit-gebannen hebbende, deese Heeren soo onmatig haare lusten volgen, dat sy vol schulden steeken, eer sy weeten dat hun goed verminderd. En hier door brengt de weelde by haer te weege het selfden, dat de behoeftigheid by de arme Luiden te veroorsaaken pleeg." Cf. the similar argument in Milton, Defence of the People of England, in Idem, Areopagitica and Other Political Writings, 250: "... the middle sort, amongst whom the wisest men and most skilful in affairs are generally found; the rest are most commonly diverted, on the one hand by luxury and wealth, on the other by want and poverty, from achieving excellence, and from the study of laws and government."

197 Welvaren 51, p. 115: "Maer die gewoon sijn rijck te weesen, beseffen, dat hare schat ... door de ongevallen ende boosheid des werelds lichtelijck kan werden verlooren ... waar door sij suinigh ende naerstigh op de huishoudingh lettende geneegen sijn hun kinderen ... in alle wetenschappen, konsten ende deughden op te brengen." 
speech addressed this question in a clearly Ciceronian vein by stressing the value of mercantile wisdom and private wealth for the commonwealth at large.$^{198}$ The De la Courts' shifting focus from the community to the individual results in a different, more ambiguous account of the good life. On the one hand, the brothers repeatedly stress the importance of public service and the civic duty to take up arms in defence of the commonwealth. On the other, they suggest that true wisdom consists of the acquiescent acceptance of one's fate, taking care of oneself while maintaining a stoic distance from "the slippery ice" of politics: "For in such a state one needs few things, and using properly the small means that one owns, one becomes with little rich and somehow God's equal, and one can live as a quiet, forgotten Citizen in his own home on his own way." ${ }^{\prime 99}$ It is such a life of modesty and utter self-reliance that characterizes those who personify the opposite of base courtly morals. Like hares in a world populated by lions, apes, foxes and parrots, these are the

People who are accustomed to live in peace from their own income without harming others, and who have nonetheless travelled many Countries, as well as learned, heard, and seen a lot. These are people who, having firm and virtuous Maxims of life, do not want to bend to pass through life more easily, and one might very well call them un-Courtiers. ${ }^{200}$

The mercantile reformation of manners of the brothers De la Court thus entails a highly politicized plea for erudition, moderation and self-sufficient perseverance vis-à-vis the threat of courtly corruption. In many ways, this plea follows Barlaeus's endeavour to appropriate the Ciceronian ethics of honour to a commercial society. Honesty and trust are necessary to maintain profitable trade, and the cultivation of personal honour is a crucial means to foster such honesty. ${ }^{201}$ Eerzucht, the civil desire to be praised, is therefore in essence a mercantile virtue. This view was shared

${ }^{198}$ Cf. the classical account in Cicero, De officiis I.XX.69-70 and I.XXVII.92.

199 Sinryke Fabulen, 222, 224: "Want men in soo eenen stande weinige saaken nodig hebbende, ende het weinige dat men heeft, wel gebruikende, met weinig rijk ende eenigsins Goode gelijk werd, ende, als een stil vergeeten Borger, op sijn eigen haard, ende naar sijnen sinne leeven kan ... Ende op hoe gladden yse de hoogste Dienaars van Staat in Republiken, daar een Vorst groot gesag heeft, ofte insonderheid onder Koningen staan."

${ }_{200}$ Ibidem, 39: "Door HAASEN, Menschen die van haar eigen inkoomen, sonder andere te beschaadigen, gewoon zijn te leven in der stilte, ende nogtans veele Landen bereisd, als meede veel geleerd, gehoord, ende gesien hebben. Dit zijn menschen die vaste ende deugdsaame Maximen van leven hebbende, niet willen krommen, om gemakkelijker door de weerelt te koomen, ende mogt men die wel on-Hoovelingen noemen."

${ }^{201} \mathrm{Cf}$. the ranting chapter against fraudulent bankruptcy in Aanwysing I.25. On the importance of honour and trust in seventeenth-century Dutch commercial society, see 
by, for example, the merchant Johan van Nyenborgh, an acquaintance of De la Court who wrote a long poem in praise of modest profits and honourable trade, referring to both Barlaeus and Cicero. ${ }^{202}$ As for Van Nyenborgh, the honest pursuit of riches is for the De la Courts an intrinsic element of such mercantile ambition, and therefore a token of true citizenship.

\section{The Wise Merchant on Canvas}

This self-confident portrayal of honourable wealth not only entails a theoretical model of mercantile manners. It is also a chief component of the way in which the brothers De la Court presented themselves in public. The De la Courts, as commercial entrepreneurs and political pamphleteers outstanding examples of the mercator sapiens, pretended to embody the ideal of wealthy and wise traders capable of honest and truthful speech. They established this image through the power of rhetoric, but also through another powerful source of self-presentation in the Dutch Golden Age: painting.

In 1657, when De la Court married Elisabeth Tollenaar, the newlywed couple was portrayed on canvas in a typical setting of domestic virtue and diligence (see fig. 11). The painting shows De la Court and his wife at a large table in the middle of their home, with a reserved yet not uninviting look to the observer who intrudes their privacy. At the right, Elisabeth is sewing, performing the duty of the obedient and caring housewife; at the left, Pieter is engaged in the bookkeeping of his firm, diligently making notes and calculations in two large volumes. The background of the panel reveals a bed that symbolizes the marital happiness behind the long green curtains. The entire rear wall of the room is occupied by a large bookcase, at the front of which stands a globe. Thus, the painting tells the viewer that this is an exemplary household of carefulness and love, virtue and learning, worldly knowledge and industry; the household, in short, of a wise merchant. ${ }^{203}$

Anne Goldgar, Tulipmania. Money, Honor, and Knowledge in the Dutch Golden Age (Chicago and London: University of Chicago Press, 2007), esp. 253-304.

${ }^{202}$ Johan van Nyenborgh, Bericht van den koophandel, in Idem, Toneel der ambachten (Groningen, 1659), esp. 166, 175, 184. Van Nyenborgh attributed one of his works to De la Court.

${ }^{203}$ The portrait of De la Court and Tollenaar, attributed to Godaert Kamper, was until recently part of the collection of the 'Diaconessenhuis' in Utrecht. See for the entire collection of paintings of the De la Court family J.H. Kernkamp, "De familie-portretten uit de collectie De la Court," in Dancwerc. Opstellen aangeboden aan prof. Dr. D. Th. Enklaar 


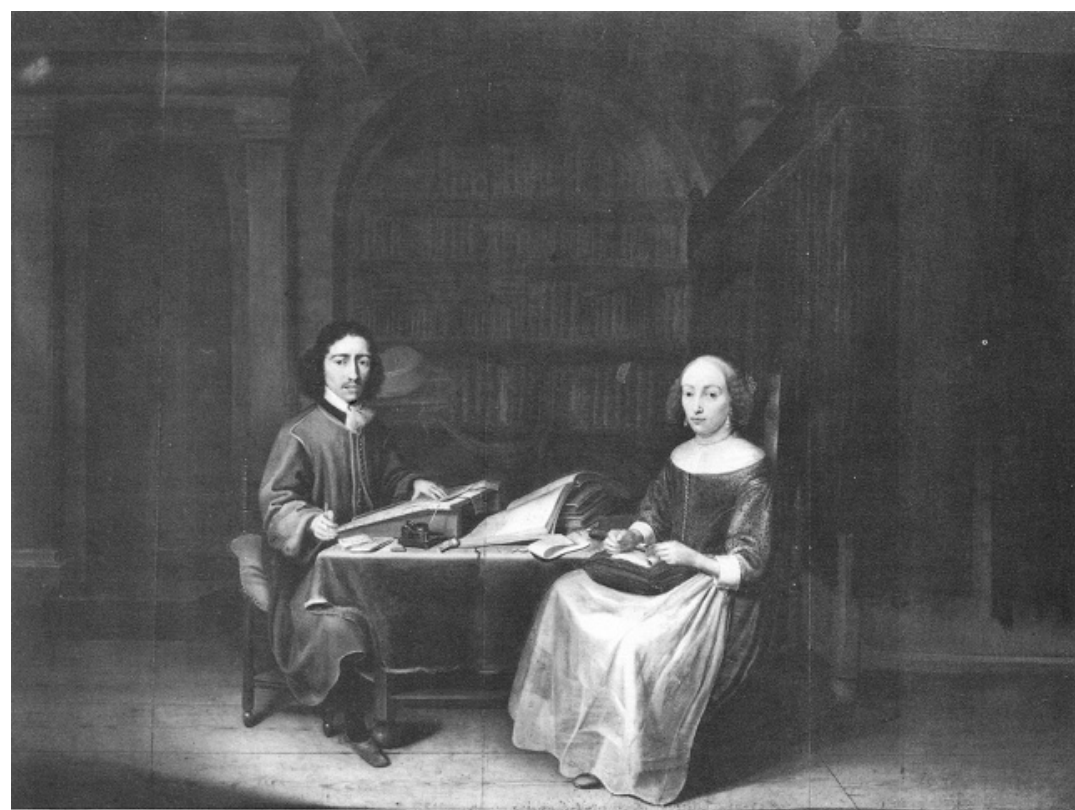

Fig. 11. Godaert Kamper, Pieter de la Court and Elisabeth Tollenaar, 1657/58. Formerly Utrecht, Diaconessenhuis. Present location unknown.

A few years after Elisabeth died in childbirth, De la Court remarried in 1661. His new bride, Catharina van der Voort, came from a very different background. She was the daughter of a rich Italian-Dutch merchant family that, after an initial period in Naples, had settled in Amsterdam, where Catharina's brothers, Giovanni and Guglielmo, continued the thriving commercial firm established by their late father. The difference between the southern Van der Voorts and the Leiden Tollenaar family is aptly revealed in a painting of Giovanni and Catharina by Ferdinand Bol, a pupil of Rembrandt who lived opposite the Van der Voorts in Amsterdam. In 1661, shortly before Catharina's wedding to De la Court, Bol portrayed the two Van der Voorts in an Italianized setting that nostalgically refers to

(Groningen: Wolters, 1959), 290-304; Idem, "De portrettering van Pieter de la Court opnieuw bekeken," in Ondernemende geschiedenis. 22 opstellen geschreven bij het afscheid van mr. H. Van Riel (The Hague: Martinus Nijhoff, 1977), 66-74; and especially C. Willemijn Fock and R.E.O. Ekkart, "De portretgalerij van de familie De la Court," Jaarboek van het Centraal Bureau voor genealogie 35 (1981), 177-230. 
their Mediterranean roots. The painting shows how brother and sister, both sumptuously dressed in the midst of a lavish garden, admire each other in a richly decorated mirror. An opened jewel case reveals the family's wealth, and in the background a copy of the Hercules Farnese completes the opulent scenery. Clearly, De la Court was about to become part of a family whose views on public appearances differed strikingly to those of his previous in-laws. ${ }^{204}$ That said, De la Court's second marriage implied that he could finally settle as a pater familias and establish his own independent household. Over the next years, Catharina gave birth to two children, Magdalena and Pieter de la Court van der Voort. In the letters that he wrote to his brothers-in-law, De la Court aptly cultivated his new status as a loving father and husband. ${ }^{205}$

To celebrate this marital happiness and increased prestige, De la Court commissioned two large separate portraits of himself and his wife from the painter Abraham van den Tempel in 1667 (colour plates A-B). The couple had moved to Amsterdam in 1665 to join Catharina's brothers, and Van den Tempel, who had worked as a textile entrepreneur in Leiden, was perhaps an old acquaintance from the De la Courts. ${ }^{206}$ With his trained eye for cloths and colours, he portrayed Catharina on a red chair in a sumptuous white satin dress with a black cloak, glistening earrings and a pearl necklace; an unfolded curtain reveals in the background a large flower vase and an extensive garden. The portrait of De la Court symmetrically mirrors that of his wife. He too is seated on a red armchair, wearing an eminent black toga with a white jabot. At the left wall, above the entrance to an arcade that leads outside, stands the quintessential symbol of wisdom and modesty: a bust of Socrates.

With such evocative imagery, De la Court aptly represented himself as a learned man who deals in rich textiles, touched by a hint of Italian splendour yet aware of the higher goal of wisdom. The addition of a

${ }^{204}$ See Albert Blankert, Ferdinand Bol (1616-1680). Rembrandt's Pupil (Doornspijk: Davaco, 1982), 153, cat. 173, plate 185. The painting is now in the Royal Museum of Arts in Antwerp.

${ }^{205}$ These letters are published in Kernkamp (ed.), "Brieven (1661-1666)" and Idem (ed.), "Brieven (1667-1685)." Cf. for the upbringing of De la Court's children Benjamin Roberts, Through the Keyhole. Dutch Child-Rearing Practices in the 17th and 18th Century. Three Urban Elite Families (Hilversum: Verloren, 1998), esp. 66-67, 79, 89-9o.

${ }^{206}$ See H.F. Wijnman, "De schilder Abraham van den Tempel," in Idem, Uit de kring van Rembrandt en Vondel. Verzamelde studies over hun leven en omgeving (Amsterdam: NoordHollandsche Uitgevers Maatschappij, 1959), 39-93. The two portraits are now part of the collection of the Amsterdam Rijksmuseum. 
bust of a classical figure was a common feature in seventeenth-century portraiture, and De la Court's choice of Socrates is revealing. In Rubens's famous painting of 'the four philosophers', Lipsius and his friends are accompanied by a bust of Seneca, as is, for example, Jacob Cats in a portrait by Arnoldus van Ravesteyn. ${ }^{207}$ Yet De la Court did not chose for the embodiment of stoic constancy but for the archetype of the engaged philosopher condemned for telling the truth - the very same theme as in the fables of the Dutchman in the Kingdom of Apes and of Actaeon who discovers Diana's nudity. The difference in emphasis and pretension with respect to De la Court's portrait with his first wife is notable (and not surprisingly, the difference in price was almost a hundredfold). ${ }^{208}$ Compared to the portraits that the parents of the brothers De la Court had commissioned in 1635 , sober depictions of a respectable and devout couple, the change is still more striking: the bible on which mother De la Court laid her hand has become the extravagant dress of Catharina van der Voort; the sandglass as a symbol of human vanity which attended De la Court sr., has become the bust of a pagan philosopher as the icon of his son. ${ }^{209}$

Accordingly, there was Pieter de la Court the diligent husband, and there was Pieter de la Court the merchant-philosopher. Eventually, there was also Pieter de la Court the orator. At the end of the 1670s, De la Court commissioned a series of portraits of his entire family from the painter Godfried Schalcken, a pupil of the art theorist Samuel van Hoogstraten. Schalcken portrayed De la Court in a brown dressing gown, nonchalantly leaning on a balustrade (see colour plate C). With his right hand performing a typical rhetorical gesture, De la Court seems to pause as during a speech. ${ }^{210}$ The wise merchant, who posed with his drapery and his books and who emulated Socrates, here addresses the spectator with the portrayal of words: he characterizes the alluring rhetoric of the market.

${ }^{207}$ Cf. on this type of portraiture Julius S. Held, "Rembrandt's Aristotle," in Idem, Rembrandt Studies (Princeton: Princeton University Press, 1991), 17-59.

${ }^{208}$ See the inventory drafted by Allard de la Court in 1749, published in Kernkamp, "Familie-portretten," 298-304, which mentions the prices paid for these paintings, respectively $f_{4},-$ and $f_{300,-.}$

${ }_{209}$ The portraits of De la Court sr. and his wife are by Pierre Dubourdieu, also a Flemish immigrant in Leiden and a friend of Van den Tempel. Both paintings are now in the Philadelphia Museum of Art. See Fock and Ekkart, "Portretgalerij," 188-190.

${ }^{210}$ See Thierry Beherman, Godfried Schalcken (Paris: Maeght Editeur, 1988), 164-165, $180-181$, cat. $65^{-66}, 82$. De la Court's portrait is part of the collection of Museum De Lakenhal in Leiden. 


\section{Conclusion: Commercial Citizenship in Perspective}

The opulence and composure with which the De la Courts presented themselves in word and in image betrays no explicit sign of any embarrassment of riches. Contrary to that which Simon Schama has typified as the main characteristic of the culture of the Dutch Golden Age, the brothers apparently saw no reason to be preoccupied with a self-assured display of their commercial wealth. ${ }^{21}$ They repeatedly argued that a modest accumulation of riches is an indication of the honourable ambition of the educated mercantile citizen who practises diligence, thrift and perseverance to counter the capriciousness of fortune. Indeed, commerce and industry share the same features as Lady Fortune, as the De la Courts suggest with a metaphor that is markedly more chivalrous than bourgeois:

Truly, industry is not an estate but a Lady (tout par amour, rien par force) who turns her back on all those who treat her forcefully, and who gives all, soul, body and goods, to the one that serves her best and takes care of her. ${ }^{212}$

For the De la Courts private wealth is the result of the mercantile virtue of knowing how to please the demanding yet voluptuous Lady Fortune. Wealth is no sign of corruption but of competence, of virtù, and therefore it is to the rich to rule the republic.

At first sight, this identification of wealth with civic virtue, couched in the language of honour and self-interest, as well as the embrace of an uncourtly life in private, seem to place the republican thought of the brothers De la Court squarely outside of the early-modern republican tradition as it has been defined by Pocock. A convinced Pocockian should conclude that the De la Courts, just like Spinoza, ultimately define "the political good as living quietly, obeying the laws and exercising liberty of mind which is a long way from the vivere civile of the Florentines". ${ }^{213}$ There is certainly a fundamental difference between the representation of the true citizen as a peaceful wise merchant and the figure of the militant landowner who serves in the enlargement of the republic as propagated by

${ }^{211}$ Schama discusses two of the De la Court' fables in his work, yet without any analysis of the general characteristics of their thought: see Schama, Embarrassment of Riches, 211, 287-288.

${ }^{212}$ Welvaren 39, p. 90: "Voorwaer neeringh is geen erf, maer een jonkvrouw (tout par amour, rien par force) die den rugge keert aen alle die haer hard handelen, en alles, siel lichaem en goed overgeeft, aen die haer best diend, en oppast." Cf. Machiavelli, Principe $\mathrm{XXV}$, p. 167: "perché la fortuna è donna ed è necessario, volendola tenere sotto, batterla e urtarla."

${ }^{213}$ Pocock, "Spinoza and Harrington," 440. 
Machiavelli and Harrington, Pocock's role models. Yet this difference does not necessarily mean that the commercial republican thought of the De la Courts was of a unique and distinctly 'modern' nature, entirely at odds with the legacy of Renaissance republicanism. ${ }^{214}$ On the contrary, a similar account of the importance of mercantile riches and a comparably hesitative evaluation of the elements of the good life of the merchant can be traced back to exactly the fifteenth-century Florentine tradition of vivere civile - albeit to a number of representatives of that tradition who are largely overlooked in Pocock's work.

Following in the footsteps of the thirteenth-century rhetorician Brunetto Latini, these civic humanists championed the importance of private fortune and commercial activity as an essential part of the life of the virtuous citizen. ${ }^{215}$ They included noteworthy humanists like Poggio Bracciolini, Matteo Palmieri, and, in particular, the famous Renaissance uomo universale Leon Battista Alberti. ${ }^{216}$ In the third book of his wellknown I libri della famiglia, composed in the 1430s, Alberti conveyed a fictional discussion between two members of his family, the aging merchant Giannozzo and the young man of letters Lionardo. The discussion can be read as a dialogue intérieur of Alberti, split apart by two conflicting views on the relation between commerce and public service. Giannozzo first propagates the quiet life of the wealthy merchant who "lives happily of his own goods". He eloquently ridicules the behaviour of the statuali, the men of state "who esteem so much to go with trumpets in front and a twig in the hand that they abstain from proper domestic repose and the true peace of mind". ${ }^{217}$ Then Lionardo stresses in reply

${ }^{214}$ Cf. Israel, "Intellectual Origins," esp. 8-17.

${ }^{215}$ See Cary J. Nederman, "Commercial Society and Republican Government in the Latin Middle Ages: The Economic Dimensions of Brunetto Latini's Republicanism," Political Theory 31 (2003), 644-663; Hans Baron, "Civic Wealth and the New Values of the Renaissance: The Spirit of the Quattrocento," in Idem, In Search of Florentine Civic Humanism. Essays on the Transition from Medieval to Modern Thought, 2 vols. (Princeton: Princeton University Press, 1988), vol. I: 226-257; Mark Jurdjevic, "Virtue, Commerce, and the Enduring Florentine Republican Moment: Reintegrating Italy into the Atlantic Republican Debate," Journal of the History of Ideas 62, 4 (2001), 721-743; and the more critical reading by Maria Luisa Pesante, "Il commercio nella repubblica," Quaderni storici 105 (2000), 655-695. See also the classical portrayal in Eugenio Garin, L'umanesimo italiano. Filosofia e vita civile nel Rinascimento (Bari: Laterza, 1993), 54-58, 74-83.

${ }_{216}$ See the biography by Anthony Grafton, Leon Battista Alberti. Master Builder of the Italian Renaissance (London etc.: Penguin, 2001), esp. 152-180.

${ }^{217}$ Leon Battista Alberti, I libri della famiglia, in Opere volgari, ed. Cecil Grayson, 2 vols. (Bari: Laterza, 1960), vol. I: 180-181: “O pazzia degli uomini! I quali tanto stimano l'andare colle trombe inanzi e col fuscello in mano, che a loro non piace più il proprio riposo 
that the good citizen will love tranquillity, but not so much his own as the one of other good men, he will enjoy his private leisure but also love the one of his other fellow citizens, he will desire the unity, peace and tranquillity of his own household, but much more the one of his fatherland and of the republic.

Gianozzo agrees, yet eventually, he has the last word. "For reigning others", he says, "never forget to reign yourselves; for guiding public affairs never forget your private ones ... [since] the public affairs never meet private needs." $^{218}$

Through the voices of Gianozzo and Lionardo, Alberti wavered between the civic ideal of public service and the commercial ideal of private gains. Ultimately he made clear that the pursuit of mercantile riches and the maintenance of self-rule are essential preconditions for the enhancement of the common good. ${ }^{219}$ It has been remarked that Alberti's dialogue thus instigated a critical reflection on the ethics of commercial activity, even though his treatise remained unpublished. ${ }^{220}$ Yet in many ways, the interplay between Gianozzo and Lionardo seems to have been restaged in the work of the brothers De la Court. Like Alberti captured in between the needs of the oikos and the demands of the polis, ${ }^{221}$ the De la Courts similarly claim the value of a peaceful and self-sufficient life in private as the best foundation of public service. They echo almost literally Alberti's emphasis on the duties of the merchant-householder, the need for thrift and frugality and the public usefulness of "the riches of private citizens", and they faithfully follow his assertion that "if gains follow from labour, diligence and our industry, then poverty, the contrary of gain, will stem from contrary things, from negligence, laziness and slowness, vices which

domestico e la vera quiete dell'animo ... A me non pare buono colui il quale non vive contento del suo proprio."

${ }^{218}$ Ibidem, 183, 185: "E affermovi che il buono cittadino amerà la tranquillità, ma non tanto la sua propria, quanto ancora quella degli altri buoni, goderà negli ozii privati, ma non manco amerà quello degli altri cittadini suoi, desiderà l'unione, quiete, pace e tranquillità della casa sua propria, ma molto più quella della patria sua e della repubblica ... per reggere altri, mai lasciate di reggere voi stessi; per guidare le cose publiche non lasciate però le vostre private ... e le cose publiche non sovvengono alle necessità private."

${ }^{219}$ See the analysis of the dialogue in Hans Baron, "Leon Battista Alberti as an Heir and Critic of Florentine Civic Humanism," in Idem, In Search of Florentine Civic Humanism, vol. I: 258-288; and cf. the slightly different reading by Viroli, From Politics to Reason of State, 96-98.

${ }^{220}$ Pesante, "Il commercio nella repubblica," 672-675.

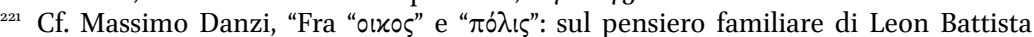
Alberti," in Claudia Bastia and Maria Bolognini (eds.), La memoria e la città. Scritture storiche tra Medioevo ed Età Moderna (Bologna: Il Nove, 1995), 47-62. 
do not lie in fortune or in external causes but in yourself". ${ }^{222}$ In short, both Alberti and the brothers De la Court characterize private mercantile wealth as the expression of civic virtue and hence the foundation of the common good of the republic.

This convergence between the republican ethics of a mercantile aristocrat from fifteenth-century Florence and two schooled entrepreneurs from seventeenth-century Holland reveals that it is doubtful whether Pieter de la Court, allegedly "ganz im geist des alten Calvinismus denkend", would have characterized Alberti's preference for a peaceful family life as "sündhafte Kreaturvergötterung" or as "aristocratische Pathetik", in line with Max Weber's famous thesis on the Protestant ethic. ${ }^{23}$ Instead, the 'capitalist spirit' of the De la Courts, like Alberti's, champions the honest pursuit of profit as a laudable civil ambition that connects the private advantage of the household with the public utility of society at large. This chapter has shown that the brothers' appeal for the disciplinary framework of civil society to overcome the possible corruption of such personal ambition follows from an essentially secular notion of the rule of law. This notion, as the brothers insist, corresponds only secondarily to the dogmas of Reformed Calvinism. Moreover, the cultivation of personal honour that underlies the mercantile ethics of the De la Courts can hardly be defined as a bourgeois ethic of asceticism. As a language of hierarchy and prestige, it entails above all a civic ethics that defines the individual citizen in relation to his fellow citizens and the commonwealth at large. ${ }^{224}$ In the De la Courts' reappraisal of Ciceronian ambition, the pursuit of profit is never for the sake of profit itself, but always for the sake of civil honour. As De la Court summarized in a private letter from 1664: "It is better to be somewhat less searching for profit and more desirous for honour ... although it conflicts with the maxims of a merchant who should, qualitate qua, search for nothing but profits." ${ }^{225}$

${ }^{222}$ Alberti, I libri della famiglia, 141-142, 144: "E sono negli ultimi casi e bisogni alla patria le ricchezze de' privati cittadini, come tutto el dì si truova, molta utilissime ... Se adunque nel guadagnare s'adempie le ricchezze, e se i guadagni seguono la fatica, diligenza e industria nostra, adunque l'impoverire contrario al guadagno diverrà dalle cose contrarie, dalla negligenza, ignavia e tardità, li quali vizii non sono in la fortuna, né in le cose estrinsece, ma in te stessi."

${ }^{223}$ Max Weber, Die protestantische Ethik. Eine Aufsatzsammlung, ed. Johannes Winckelmann, 2d. ed. (München and Hamburg: Siebenstern, 1969), 51, 86.

${ }^{224}$ Cf. Schama, Embarrassment of Riches, 568-569.

${ }_{225}$ Pieter de la Court to the brothers Van der Voort, 7 July 1664, in J.C. Overvoorde (ed.), "De Noord-Oostelijke doorvaart naar China," Bijdragen en mededelingen van het historisch genootschap 47 (1926), 249-331, 270: “... beeter is 't wat min baatsoekende en meer 
On the basis of several different strands of thought concerning human nature, the origin of society, the rights and duties of citizens and the morals of the market, the brothers De la Court constructed an account of commercial citizenship that merged a principled anti-monarchism with an appeal for honourable trade and mercantile wealth. First, the De la Courts appropriated the fashionable writing of Hobbes to argue that all legitimate government originates in democratic consent. Reading Hobbes through Grotian lenses, they radicalized mainstream contract theory with the claim that a true civil society can never be a monarchy. Instead, sovereignty remains indivisibly with the community of contractors, the householders who constitute the ruling citizenry. While critical of the exclusivist practice of seventeenth-century Dutch citizenship, the De la Courts maintained a mainstream definition of this citizenry as the collective of free, independent males who represent their household in the hierarchies of urban society. These merchant citizens, who actively participate in the defence and the decision-making of the polity, harness the defining human passion of self-love towards honourable ambition. Contrary to the corrupting mores of a monarchical court, the disciplinary framework of a true civil society enables such a sincere pursuit of self-interest in connection to the common good - the virtue that reveals itself in the wealth and erudition of those who embody non-monarchical manners: the wise merchants. This intrinsic connection between republicanism and trade applies not only to the individual level of citizenship, but also to the general level of the commercial commonwealth at large.

eergierig te zijn ... hoewel 't strijd teegen maximen van een koopman, die qualitate qua niet dan profijt soeken moet." 